\title{
O PRACACH RZEŹBIARSKICH ANTONIEGO POPIELA DLA JASIELSKICH FRANCISZKANÓW
}

\author{
Pamięci Mojej Babci, Stanisławy Tułeckiej, \\ czcicielki św. Antoniego, \\ w stulecie obecności figury św. Antoniego w Jaśle
}

\section{Wprowadzenie}

Niewiele jest chyba w Jaśle osób, które nie znałyby historii franciszkańskiej figury św. Antoniego, jej bliskiego związku z tragicznymi momentami w historii miasta i - w konsekwencji - faktu uznania św. Antoniego patronem Jasła ${ }^{1}$. $\mathrm{W}$ rezultacie figura ta postrzegana jest powszechnie jako obiekt otaczany religijnym kultem, tymczasem z punktu widzenia historii sztuki stanowi ona również interesujące dzieło sztuki, wykonane przez cenionego na przełomie XIX i XX wieku, kojarzonego ze Lwowem, artystę rzeźbiarza Antoniego Popiela. Co więcej, figura ta nie była pierwotnie samoistnym, indywidualnym dziełem sztuki, lecz zaledwie jednym z elementów wystroju ołtarza głównego, a szerzej: jednym z wielu elementów dekorujących pierwotny kościół franciszkanów w Jaśle, dzisiaj już nieistniejący². To właśnie tym elementom, ich twórcy oraz jego współpra-

* Andrzej Laskowski - dr historii sztuki, adiunkt w Zakładzie Dziedzictwa Kulturowego i Studiów Miejskich UNESCO, Uniwersytet Ekonomiczny w Krakowie, e-mail: andrzej.laskowski@ uek.krakow.pl

${ }^{1}$ Spora w tym zasługa Zdzisława Świstaka, który skrupulatnie opisał dzieje jasielskiej figury od momentu jej powstania po współczesność oraz rozwój kultu świętego w naszym mieście, przygotowując okolicznościową publikację (por.: Święty Antoni Padewski. Patron Jasła, oprac. Z. Świstak, Jasło 1996).

${ }^{2}$ Jest to kolejny z moich tekstów poświęconych jasielskim franciszkanom i związanym z nimi dziełom sztuki. Wcześniejsze zob.: A. Laskowski, A. Organisty, Uwagi na temat barokowego obrazu „Stygmatyzacja św. Franciszka” w kościele OO. Franciszkanów w Jaśle, „Rocznik Jasielski”, 4 (1999), s. 19-28; A. Laskowski, Przybycie i pierwsze lata pobytu w Jaśle OO. Franciszkanów i SS. Wizytek $w$ świetle akt miejskich (do roku 1918), „Prace Historyczno-Archiwalne”, 7 (1999) 
cownikom chciałbym poświęcić niniejszy tekst, koncentrując szczególną uwagę na figurze św. Antoniego, jako jedynym zachowanym w Jaśle do dzisiaj dziele tego cenionego artysty ${ }^{3}$.

\section{Stan badań}

Jako pierwszy działalność artystyczną Antoniego Popiela na rzecz jasielskich franciszkanów odnotował ks. Władysław Sarna i to już w 1908 roku. Z twórcą tym związał on jednakże tylko figurę św. Antoniego, umieszczoną wówczas w niszy głównego ołtarza kościoła ${ }^{4}$. Przez kolejne dziesięciolecia nie dostrzegano ani historycznych, ani artystycznych walorów prac lwowskiego artysty ${ }^{5}$. Dopiero fundamentalne badania historyczne Zdzisława Świstaka, odwołujące się do materiałów źródłowych, pozwoliły mu na opublikowanie w 1995 roku cennych wzmianek o działalności lwowskiego rzeźbiarza na rzecz jasielskich franciszkanów, tj. montażu figury Matki Boskiej na fasadzie kościoła, podjęciu prac przy ustawianiu głównego ołtarza (z figurą św. Antoniego na centralnym miejscu) oraz usytuowaniu w jego niszach bocznych wykonanych przezeń figur św. Alfonsa i św. Franciszka Salezego ${ }^{6}$. Rok później powstało odrębne opracowanie tego autora, dedykowane św. Antoniemu jako patronowi Jasła; zostały w nim przywołane najważniejsze fakty dotyczące powstania i losów figury tego świętego ${ }^{7}$. W 2007 roku autor niniejszego artykułu, bazując na dotychczasowej literaturze przedmiotu oraz archiwaliach franciszkańskich z Krakowa, wzmiankował w książce poświęconej Jasłu w okresie autonomii galicyjskiej fakt wykonania przez Antoniego Popiela pięciu dzieł do przedwojennej franciszkańskiej świątyni: trzech figur do głównego ołtarza oraz figury Matki Boskiej i godła zakonnego umieszczonych na ścianie frontowej wieży kościoła ${ }^{8}$. Cztery lata później, ten sam autor omówił

s. 113-127; A. Laskowski, Między rzemiostem a sztuka. Saga rodu Ungerów, w: Sztuka witrażowa w Polsce, red. J. Budyn-Kamykowska, K. Pawłowska, Kraków 2002, s. 117-132; tenże, Nieistniejacy kościót Franciszkanów w Jaśle i jego twórca Michał Łużecki. Przyczynek do biografii, „Sacrum et Decorum", 4 (2011) s. 20-43.

${ }^{3} \mathrm{Na}$ aspekt ten starałem się zwrócić uwagę podczas obchodów Dni Jasła w 2011 roku, wzmiankując m.in. jasielską figurę św. Antoniego w swoim popularno-naukowym referacie zatytułowanym Utracone - ocalone - sprawione. Wkład jasielskich franciszkanów w ksztaltowanie kultury materialnej Jasta.

${ }^{4}$ W. Sarna, Opis powiatu jasielskiego, Jasło 1908, s. 262. Równocześnie autor ten błędnie podał nazwisko twórcy ołtarza (miała go wykonać pracownia Sulikowskiego we Lwowie), co skorygował później Z. Świstak, Franciszkanie w Jaśle, Jasło 1995, s. 16, pisząc o lwowskim rzeźbiarzu Sokulskim jako rzeczywistym autorze ołtarza.

${ }^{5}$ Jego działalności nie odnotował nawet w swej fundamentalnej przez długi czas pracy na temat zabytków Jasła Juliusz Ross, co wynikało jednak z dość powszechnego wówczas pozostawania sztuki doby historyzmu poza obszarem badań historyków sztuki (zob.: J. Ross, Zabytki Jasta i okolicy, w: Studia z dziejów Jasta i powiatu jasielskiego, red. J. Garbacik, Kraków 1964, s. 631-647, franciszkanie na s. 637).

${ }^{6}$ Świstak, Franciszkanie, s. 16 i 19.

${ }^{7}$ Por. przyp. 1.

${ }^{8}$ A. Laskowski, Jasło $w$ dobie autonomii galicyjskiej. Miasto i jego przestrzeń, Kraków 2007, s. 67. 
architekturę dawnego kościoła franciszkanów w Jaśle, poświęcając wiele uwagi jego projektantowi oraz wskazując na współpracujących z nim przy dekorowaniu elewacji i wyposażaniu wnętrza kościoła artystów ze Lwowa9 9

\section{Historia}

17 maja 1903 roku biskup przemyski ks. Józef Sebastian Pelczar poświęcił kamień węgielny pod budowę kościoła franciszkanów w Jaśle, inicjując tym samym długo wyczekiwane dzieło jego wznoszenia. Pomimo początkowych trudności, szybko postępujące prace sprawiły, że 11 października 1904 roku hełm wieży kościoła zwieńczył krzyż, symbolizując zbliżające się do końca prace budowlane ${ }^{10}$. 15 listopada tego roku wykonana przez Antoniego Popiela kamienna figura Matki Boskiej została przywieziona koleją ze Lwowa (zapłacono za to 10,28 złotych reńskich), a następnie $\mathrm{z}$ dworca kolejowego w Jaśle przetransportowano ją na plac budowy (za transport i wynajęcie pomocników zapłacono 2,57 złotych reńskich $)^{11} .29$ listopada figura ta zdobiła już ścianę frontową kościelnej wieży, a od 12 grudnia lwowski rzeźbiarz Sokulski rozpoczął ustawianie głównego ołtarza ${ }^{12}$. 27 grudnia tego roku przywieziono do Jasła figurę św. Antoniego (płacąc za to 5 koron i 81 halerzy), kolejne dzieło Popiela, po czym ustawiono ją w centralnym miejscu głównego ołtarza. 31 grudnia 1904 roku odbyło się uroczyste poświęcenie kościoła ${ }^{13} .5$ czerwca 1905 r. franciszkanie zapłacili 130 koron za kamień na godło do fasady, 15 czerwca - 14 koron za obrobienie tego kamienia, a pod koniec lipca - 10 koron czeladnikowi Antoniego Popiela, Albrychtowi, za podróż do Lwowa, zapewne po zakończeniu prac przy godle. Ze zbiorczego zestawienia wydatków na prace w Jaśle (sporządzonego we Lwowie w dniu 24 czerwca 1905 roku przez prowincjała o. Benignego Chmurę, a obejmującego okres od 1 grudnia 1903 roku) wynika, że Antoni Popiel otrzymał w tym okresie należność w wysokości 1500 koron za figury (zapewne za kamienną figurę Matki Boskiej na fasadę i drewnianą figurę św. Antoniego do ołtarza głównego), natomiast za ołtarz (chodzi zapewne o ołtarz główny i należność dla Sokulskiego) franciszkanie zapłacili 3060 koron.

Przed Bożym Narodzeniem 1905 roku Antoni Popiel nadesłał do Jasła figury św. Alfonsa i św. Franciszka Salezego, przeznaczone do głównego ołtarza. W po-

\footnotetext{
${ }^{9}$ Laskowski, Nieistniejący kościót, s. 22-31 i 41.
}

${ }^{10}$ Świstak, Franciszkanie, s. 15-16.

${ }^{11} \mathrm{Tu}$ i dalej w tym akapicie wykorzystano dokumenty zgromadzone w: Archiwum Prowincji Św. Antoniego Padewskiego i Bł. Jakuba Strzemię OO. Franciszkanów w Krakowie (dalej: APF), sygn. D-II-53, teczka D-I JASŁO-10 (Dochody i wydatki związane z budową kościoła w Jaśle w latach 1902-1906), chyba że zaznaczono inaczej. Tu właśnie, w odrębnym zestawieniu wydatków, odnajdujemy pod datą roczną 1905 potwierdzenie wydanej kwoty $140 \mathrm{~K}$ opisanej jako: „za kamień na godło i kamieniarz".

${ }^{12}$ Świstak, Franciszkanie, s. 16. Fundatorem ołtarza głównego był o. definitor Alfons Ptaszek (wg: APF, sygn. E-I-59, s. 106). Zapewne z tej racji jako pierwszy, w niedzielę 1 stycznia 1905 roku o godz. 8.00, odprawił on pierwszą mszę św. w nowym kościele przed głównym ołtarzem (Świstak, Franciszkanie, s. 18).

${ }^{13}$ Świstak, Franciszkanie, s. 17. 
łowie stycznia 1906 roku prosił prowincjała o rozliczenie tej pracy, której koszt ustalony był umową na 600 koron (po 300 koron za każdą figurę), a za które rzeźbiarz miał jeszcze otrzymać 260 koron (wobec wypłaconej mu już zaliczki w kwocie 300 koron i 40 koron naddatku otrzymanych przy poprzednim rozliczeniu $)^{14}$. Figury te jeszcze 23 grudnia 1905 roku ustawiono w ołtarzu głównym, po bokach figury św. Antoniego, kompletując tym samym zespół dzieł autorstwa Antoniego Popiela w jasielskiej świątyni (fot. 1) ${ }^{15}$. Rychło w nowo urządzonym kościele zaczął szerzyć się kult św. Antoniego, a przy figurze w głównym ołtarzu, począwszy od 7 lutego 1905 r., zaczęły pojawiać się dziękczynne wota ${ }^{16}$.

Po wysiedleniu mieszkańców Jasła we wrześniu 1944 roku, od 5 lub 6 grudnia tego roku Niemcy rozpoczęli systematyczne niszczenie świątyni franciszkańskiej, podpalając ją, a następnie wysadzając $\mathrm{w}$ powietrze ${ }^{17}$. $Z$ tej pożogi, po blisko pół roku, w połowie czerwca 1945 roku, robotnicy pracujący przy odgruzowaniu miejsca po kościele, wydobyli niemal zupełnie nieuszkodzoną figurę św. Antoniego (fot. 2) ${ }^{18}$. Był to jedyny element dekoracyjny wykonany niegdyś dla jasielskich franciszkanów przez Antoniego Popiela, który przetrwał wojnę.

Po wydobyciu z ruin kościoła, figura nawiedzana była przez Jaślan, stojąc najpierw na podwórzu klasztornym, a przez następne trzy dni w kuchni klasztornej. Wkrótce poddano ją pracom konserwatorskim (ich wykonawcą był ks. Władysław Lutecki z Przemyśla ${ }^{19}$; brakujący element - część rękawa przy dłoni świętego - uzupełnił jasielski rzeźbiarz Stanisław Piątkiewicz ${ }^{20}$ ) i umieszczono w głównym ołtarzu tymczasowej kaplicy, jaką franciszkanie zaaranżowali w ocalałym budynku swego dawnego klasztoru. Nawiedzana przez liczne rzesze wiernych, obdarowywana była wotami, ciesząc się powszechną czcią (fot. 3) ${ }^{21}$. 6 października 1963 roku, w dniu poświęcenia nowego kościoła franciszkanów w Jaśle (zlokalizowanego na nowym miejscu, u zbiegu ulic 3 Maja i Szopena), figurę przeniesiono $\mathrm{w}$ uroczystej procesji do nowej świątyni, umieszczając ją w jej

${ }^{14}$ APF, sygn. D-II-44, teczka D-II JASŁO-3 (zob. aneks).

${ }^{15}$ Świstak, Franciszkanie, s. 19. Tak ustalony stan omawianych obiektów utrzymał się zasadniczo do schyłku okupacji i wysadzenia kościoła w powietrze. Wiadomo, że w 1937 roku noszono się z zamiarem przerobienia oświetlenia elektrycznego na głównym ołtarzu i planowano dać po bokach dwa wielkie kandelabry elektryczne za około $300 \mathrm{zl}$ - zob.: APF, sygn. D-II-45, teczka D-II JASŁO-4 (list o. gwardiana Peregryna Haczeli do o. prowincjała z dnia 2 listopada 1937 r. z prośbą o zatwierdzenie tej inwestycji, która - jak wynika z listu - została już miesiąc wcześniej zaaprobowana przez kapitułę konwencką).

16 Świstak, Franciszkanie, s. 23.

${ }^{17}$ Tamże, s. 41.

${ }^{18}$ Fakt ten udokumentował jasielski malarz i fotograf-dokumentalista Stanisław Witowski -Iskrzyniak. Figura była nienaruszona, jedynie w brodę świętego wbił się ołowiany odłamek, pochodzący najpewniej z jednego z witraży w prezbiterium (Świstak, Franciszkanie, s. 44-45).

${ }^{19} \mathrm{O}$ ks. Luteckim zob.: K. Wolski, Lutecki Władysław, w: Polski słownik biograficzny konserwatorów zabytków, z. 3, Warszawa 2009, s. 80-81.

${ }^{20}$ Zob. wzmiankę o nim w: Laskowski, Jasło $w$ dobie autonomii, s. 67.

${ }^{21}$ Świstak, Franciszkanie, s. 45. 
wnętrzu, gdzie pozostaje do dnia dzisiejszego ${ }^{22} .27$ marca 1996 roku Rada Miasta w Jaśle podjęła uchwałę uznającą św. Antoniego Padewskiego patronem Jasła, do czego walnie przyczynił się jego kult szerzony przez franciszkanów i modlitwy kierowane do świętego przy jego figurze, dłuta Antoniego Popiela ${ }^{23}$.

\section{Opis rekonstrukcyjny}

Wobec tragicznych losów pierwszej świątyni franciszkańskiej w Jaśle, dokonując opisu prac Antoniego Popiela dla tego kościoła, zmuszeni jesteśmy w większości przypadków bazować na nielicznych dawnych fotografiach, często słabej jakości i nie koncentrujących się szczególnie na interesujących nas dziełach sztuki, względnie odwoływać się do lakonicznych przekazów archiwalnych. Z tego względu jest to zasadniczo opis rekonstrukcyjny, w którym jedynie drewniana figura św. Antoniego, chociaż poddana po II wojnie światowej kilkukrotnemu odnowieniu, daje względne pojęcie o pierwotnym charakterze opisywanych tu prac rzeźbiarskich A. Popiela.

Najbardziej wyeksponowanym dziełem A. Popiela w Jaśle była wykonana z piaskowca ${ }^{24}$, najpewniej z jednego bloku kamienia, figura Matki Boskiej Niepokalanie Poczętej (fot. 4 i 5). Wynikało to $z$ faktu, że ustawiona została na osi głównej wieży poprzedzającej korpus nawowy kościoła, od jej frontu, w ostrołukowo zakończonej wnęce znajdującej się w schodkowym szczycie nad głównym wejściem do świątyni. Cechą charakterystyczną tej lokalizacji było silne wysunięcie figury przed lico ściany wieży, dzięki czemu rzeźba była doskonale widoczna nie tylko od frontu, ale także z obu boków kościoła. Ukazywała Marię odzianą w płaszcz, z rozłożonymi rękoma o otwartych dłoniach, na które spływały poły płaszcza. Z gestu tego wolno się domyślać, iż była to figura w często występującym w sztuce barokowej i bardzo popularnym w XIX-wiecznej sztuce sakralnej typie Matki Boskiej Niepokalanie Poczętej, w którym Niepokalana, stojąc na globie, depcze węża, symbolizującego szatana. W kontekście miejsca na kościelnej fasadzie, jaki wyznaczono figurze, gest rozłożonych dłoni interpretować można także jako swoiste zaproszenie wiernych do wstąpienia w progi świątyni.

Drugie, silnie niegdyś wyeksponowane dzieło Popiela, również umieszczone na fasadzie kościoła, to płaskorzeźbione, wykonane z kamienia (zapewne $\mathrm{z}$ piaskowca) godło franciszkańskie (fot. 4 i 5). Zgodnie z tradycją ukazywało ono wyłaniające się z obłoku: krzyż (na osi) oraz - po bokach krzyża - skrzyżowane ręce z otwartymi dłońmi, z których jedna (naga) należała do Chrystusa, a druga (w habicie) do św. Franciszka, założyciela zakonu ${ }^{25}$. Godło to znalazło się poniżej figury, nad samym otworem wejściowym do kościoła, stanowiąc de facto tympanon

${ }^{22}$ Tamże, s. 66-67. Figura ta była w obrębie nowej świątyni wielokrotnie przemieszczana, stanowiąc element różnych ołtarzy, dopóki u schyłku XX w. nie zaaranżowano dla niej specjalnej kaplicy, usytuowanej na zakończeniu lewej nawy kościoła.

${ }^{23}$ Zob.: Św. Antoni Padewski, s. 29-38.

${ }^{24}$ Informację taką podaje Świstak, Franciszkanie, s. 16. Znajduje ona potwierdzenie w materiałach archiwalnych.

${ }^{25}$ O godle franciszkańskim zob.: W. Kolak, J. Marecki, Leksykon godet zakonnych, Łódź 1994, s. $51-52$. 
głównego portalu świątyni. Był to element dosyć płaski, subtelnie wkomponowany w strukturę wieży, jako element dekoracyjny nie stanowiący konkurencji dla figury Matki Boskiej, pełniący głównie funkcję informacyjną, mającą uświadamiać wiernym, że wstępują do świątyni należącej do wspólnoty franciszkańskiej.

Pozostałe trzy prace A. Popiela, tj. figury św. Antoniego, św. Alfonsa i św. Franciszka Salezego, powstały jako kluczowe elementy dekoracyjne ołtarza głównego kościoła. Ołtarz ten, znany jedynie z archiwalnych zdjęć wnętrza świątyni (fot. 6) i opisu sporządzonego w 1919 roku $^{26}$, utrzymany był, podobnie jak kościół, w stylistyce neogotyckiej, operował zatem elementami zaczerpniętymi z gotyku. Usytuowany tradycyjnie na osi głównej kościoła, na końcu prezbiterium, zajmował całą szerokość zamykającej je ściany, dzięki czemu flankujące ołtarz ostrołukowe okna były naturalnym źródłem jego oświetlenia. Struktura ołtarza była trójosiowa; w jej centrum, ponad tabernakulum, znajdowała się zamknięta oślim grzbietem i uzupełniona ażurową dekoracją maswerkową arkada, stanowiąca architektoniczną oprawę dla figury św. Antoniego. Po bokach, symetrycznie względem centralnej arkady, ulokowane były ażurowe baldachimy, pod którymi ustawione były figury św. Alfonsa i św. Franciszka Salezego. Wielkością i w proporcjach zbliżone do figury św. Antoniego, ustawione były od niej niżejtak, iż podstawa tej ostatniej wypadała mniej więcej w $2 / 3$ wysokości figur bocznych. Główne osie ołtarza wieńczyły strzeliste pinakle znacząco uwysmuklające strukturę całego ołtarza, szerszego i wyższego w części centralnej. Tym samym ołtarz idealnie dopasowywał się do nowo powstałego wnętrza, udanie wykorzystując narzucone przez architekturę źródła światła.

Jedynym zachowanym do dzisiaj elementem opisanego ołtarza jest figura św. Antoniego z Padwy (fot. 7). Zgodnie z tradycją ikonograficzną ukazuje ona stojącą postać świętego ubranego $\mathrm{W}$ franciszkański habit przepasany sznurem, z przewieszonym przezeń różańcem, trzymającego w prawej dłoni sporych rozmiarów lilię ${ }^{27}$, a w lewej dłoni dzierżącego zamkniętą księgę, symbol nauki, na której przysiadło w swobodnej pozie Dzieciątko Jezus; ubrane w luźną, jasną szatę obwiedzioną na krawędziach szeroką, złotą taśmą, z ufnością dotyka ono prawą dłonią podbródka świętego, a lewą dłoń trzyma na zwieńczonym krzyżem jabłku, będącym jedynym atrybutem władzy królewskiej Chrystusa występującym w Jaśle. Obie postaci posiadają zamontowane od tyłu nimby w postaci cienkich, metalowych obręczy ${ }^{28}$.

Poza obu postaci jest swobodna, dzięki czemu dosyć masywna figura sprawia wrażenie lekkiej. Św. Antoni ukazany został w klasycznym kontrapoście: prawą

${ }^{26}$ Czytamy w nim: „Ołtarz wielki, drzewiany, gotycki, polichromowany na dębowo i złocony szczytem sięga sklepienia. W nim figura św. Antoniego z Dzieciątkiem w nyży stojąca, a niżej ponad gotyckim tabernakulum mały obrazek na płótnie M. B. Nieustającej Pomocy. Koło figury i obrazów wisi kilka wotów. Po bokach są figury św. Alfonsa i św. Franciszka" (podaję za: Świstak, Franciszkanie, s. 145, przyp. 44).

${ }^{27}$ Jak wykazały oględziny dokonane po wydobyciu figury z gruzów wysadzonego w powietrze kościoła, element ten był wykonany z blachy (por.: Świstak, Franciszkanie, s. 45).

${ }^{28}$ Posiadały je już w chwili wydobycia z ruin, co pozwala domniemywać, iż były elementem dzieła od samego początku. 
nogę ugina w kolanie, aby zrównoważyć ciężar trzymanego na lewej ręce Dzieciątka. Nagie stopy świętego, obute w sandały, spoczywają na wielobocznej podstawie, która miała stabilizować figurę i ułatwiać jej montaż na ołtarzu. Święty ma twarz zamyśloną, jakby nieobecną, pełną niepokojącego przeczucia co do losu Dziecka. Mały Jezus ma twarz pełną ufności i nadziei, ze wzrokiem skierowanym ku niebu; gestem prawej dłoni stara się dodać strapionemu świętemu otuchy (fot. 8).

Figura św. Antoniego stanowiła najbardziej wyeksponowany element ołtarza głównego w dawnym kościele franciszkańskim w Jaśle. Asystujące jej figury św. Alfonsa i św. Franciszka Salezego, usytuowane w ołtarzu niżej i będące chyba nieco mniejszych rozmiarów, nie są dzisiaj możliwe do opisania. Można się jedynie domyślać, że zgodnie z tradycją, pierwszy święty ukazany został w czarnej sutannie zakonnej lub w szatach biskupich, z krzyżem w ręku lub różańcem na szyi, a drugi w stroju biskupim i z którymś ze swoich atrybutów (gorejącą kulą z ośmioma płomieniami, księgą, piórem lub sercem trzymanym w dłoni).

\section{Zarys problematyki artystycznej}

Zakładana na przełomie XIX i XX wieku nowa placówka franciszkańska w Jaśle, znajdowała się w centrum uwagi całej wspólnoty. Jak zaznaczył w swych pamiętnikach franciszkanin o. Alojzy Karwacki, Jasło było jedyną nową placówką franciszkanów, jaka powstała w XIX wieku w prowincji polskiej, ruskiej i litewskiej ${ }^{29}$. W związku z tym mogła liczyć na szczególne traktowanie i szczególną dbałość o jakość, także w sensie artystycznym, tak samego kościoła, jak i jego wyposażenia. Ówczesne usytuowanie władz prowincji franciszkańskiej we Lwowie zdeterminowało natomiast kierunek poszukiwań architektów i rzemieślników mających wznieść i udekorować jasielski kościół. I chociaż w Jaśle wydatnie skorzystano z umiejętności lokalnego środowiska, to jednak kluczowe kwestie artystyczne spoczęły w ręku twórców związanych na co dzień ze Lwowem. To w nim silnie zakorzeniony był projektant kościoła Michał Łużecki ${ }^{30}$, to w nim działali m.in. Antoni Popiel, Tadeusz Sokulski i Andrzej Albrycht, w różnym stopniu zaangażowani w proces wzbogacenia świątyni elementami rzeźbiarskimi.

Antoni Popiel ${ }^{31}$, główna postać niniejszych rozważań, urodził się 13 czerw-

${ }^{29}$ Zob.: APF, sygn. E-I-59: Pamiętnik X. Alojzego Karwackiego franciszkanina od czasu wstapienia do Zakonu w 1883 roku, a spisywane od r. 1902, mps, s. 100. O. Alojzy Karwacki by1, jak sam pisze (Świstak, Franciszkanie, s. 101), pierwszym zakonnikiem franciszkańskim, który w październiku 1899 roku przybył do Jasła.

${ }^{30}$ Zob.: A. Laskowski, Kadra techniczno-budowlana zwiąana z Jastem w okresie autonomii galicyjskiej. Słownik biograficzny, Kraków 2003, s. 92-94, a zwłaszcza: Laskowski, Nieistniejący kościót, s. 20-43.

31 Podstawowe dane biograficzne podaję za: P. Szubert, Popiel (Sulima-Popiel) Antoni, w: Stownik artystów polskich i obcych w Polsce działajacych (zmartych przed 1966 r.). Malarze - rzeźbiarze - graficy (dalej: SAP), t. 7: Pe-Po, Warszawa 2003, s. 393-396. Zob. także: Popiel Antoni, w: E. Swieykowski, Pamiętnik Towarzystwa Przyjaciót Sztuk Pięknych w Krakowie 18541904, Kraków 1905, s. 225 oraz P. Błoński, Popiel (Sulima Popiel) Antoni (1865-1910), w: Polski słownik biograficzny (dalej: PSB), t. 27, Kraków 1983, s. 553. Ostatnio o twórcy tym pisał obszernie J. Biriulow, Antoni Popiel - twórca pomnika Mickiewicza, w: Studia o artystach XVIII-XX wieku, 
ca 1865 roku w Szczakowej, jednak do gimnazjum uczęszczał we wschodniej części Galicji, tj. w Brodach i we Lwowie, co wynikało z mobilnego charakteru pracy jego ojca, urzędnika celnego. W latach 1882-1885 Antoni studiował w krakowskiej Szkole Sztuk Pięknych, gdzie jego nauczycielami byli m.in. Władysław Łuszczkiewicz i Walery Gadomski, a następnie kontynuował naukę w Wiedniu, studiując w latach 1885-1888 pod kierunkiem Edmunda Hellmera w tamtejszej Akademii Sztuk Pięknych oraz w Österreichisches Museum für Kunst und Industrie, w pracowni Otto Königa. Kończąc edukację odwiedził Berlin i Florencję, po czym na pewien czas osiadł w Krakowie, by następnie zostać asystentem cenionego polskiego rzeźbiarza włoskiego pochodzenia, Leonarda Marconiego ${ }^{32}$, w prowadzonej przezeń katedrze rysunku i modelowania Politechniki Lwowskiej. Krok ten zdeterminował całą jego późniejszą karierę, bowiem A. Popiel nie tylko do końca życia pozostał wierny lwowskiej uczelni, ale też poślubił wkrótce (w 1895 roku) córkę Marconiego, Marię Cyprianę. Wraz z nią spędził kolejne lata (1895-1897) we Florencji, pracując równocześnie nad pierwszymi prestiżowymi zamówieniami dla Galicji: posagiem Justitia (Sprawiedliwość) do westybulu Pałacu Sprawiedliwości we Lwowie oraz pomnikiem Józefa Korzeniowskiego dla Brodów (który był darem rzeźbiarza dla miasta jego młodości). W 1898 roku kilka miesięcy spędził w Warszawie. W rezultacie prowadzonych tam prac projektowych otrzymał nagrodę w konkursie na dekorację rzeźbiarską fasady nowego gmachu Towarzystwa Zachęty Sztuk Pięknych (projekt ten nie został jednak zrealizowany). Prawdziwym przełomem w jego karierze było jednak odniesione w tym samym roku zwycięstwo w prestiżowym konkursie na pomnik Adama Mickiewicza we Lwowie (pomnik ten odsłonięto jesienią 1904 r.).

Kiedy zmarł L. Marconi (w nocy z 1 na 2 kwietnia 1899 roku we Lwowie), A. Popiel przejął zawodowe zobowiązania teścia. Spośród nich najbardziej spektakularnym dziełem był niewątpliwie wyjątkowy, bo monumentalny, konny pomnik Tadeusza Kościuszki w Krakowie (po licznych perturbacjach ustawiony na Wawelu dopiero w 1924 roku, pomimo przygotowania go już w latach 18991900). Wykonanie tak znanych prac, przy równoczesnej opinii o kontynuowaniu przezeń artystycznej drogi L. Marconiego sprawiło, że A. Popiel zaczął otrzymywać bardzo dużo prestiżowych zleceń, zarówno w stołecznym Lwowie, jak i w mniejszych miastach Galicji. Z prac lwowskich wymienić należy przede wszystkim rzeźby dekoracyjne (tympanon oraz kariatydy i posągi muz na attyce) do gmachu Teatru Miejskiego (1900), rzeźby na fasadzie dworca głównego (1904) oraz liczne elementy wyposażenia tzw. Złotej Kaplicy w kościele jezuitów (1905). Poza Lwowem na szczególną uwagę zasługują: popiersie Henryka Rodakowskiego zdobiące elewację Pałacu Sztuki w Krakowie (1901), ołtarz i grupa Pietà w kaplicy grobowej Potockich przy kościele parafialnym w Łańcucie (przed 1904) czy pomnik Adama Mickiewcza w Krynicy (1901-1906). Efekty swojej twórczości prezentował lub pozostawił również zagranicą. Zaliczyć do nich moż-

red. J. Malinowski, Toruń 2003, s. 87-116 oraz J. Biriulow, Rzeźba lwowska od połowy XVIII wieku do 1939 roku. Od zapowiedzi klasycyzmu do awangardy, Warszawa 2007, passim (w szczególności s. 115-122).

${ }^{32}$ Szeroko pisze o jego twórczości Biriulow, Rzeźba lwowska, passim (zwłaszcza s. 152-161). 
na udział w wystawie sztuki austriackiej w Londynie (1906; gdzie eksponowano jego rzeźbę zatytułowaną Szatan), płaskorzeźbę ku czci Fryderyka Chopina w Karlsbadzie (1908), a przede wszystkim pomnik Tadeusza Kościuszki w Waszyngtonie, odsłonięty w 1911 roku (już po śmierci rzeźbiarza), a zrealizowany w następstwie konkursu z 1907 roku, w którym Popiel otrzymał wprawdzie II nagrodę, ale osobistą decyzją ówczesnego prezydenta Stanów Zjednoczonych Theodore Roosvelta to właśnie jego projekt przeznaczony został do realizacji i stanął na placu La Fayette'a przed Białym Domem. Rzecz godna uwagi, iż prace przy tym monumentalnym dziele prowadził A. Popiel na miejscu, w Stanach Zjednoczonych, skąd jednak był zmuszony wyjechać ze względu na pogarszający się stan zdrowia.

A. Popiel, skupiony na licznych, bieżących zleceniach, brał udział w niewielu wystawach. Natomiast sporo swego czasu angażował w pracę pedagogiczną. Koncentrowała się ona na macierzystej katedrze na Politechnice Lwowskiej, której prowadzenie przejął po śmierci L. Marconiego, ale znajdowała też upust w działaniach społecznych, jak chociażby w założonym m.in. przezeń stowarzyszeniu Młoda Sztuka, które stawiało sobie za cel popieranie młodych artystycznych talentów. Z podobnych względów nazwisko A. Popiela łączy się ze Stanisławem Szukalskim (1893-1987) ${ }^{33}$, którego talent Popiel dostrzegł podczas swego pobytu w Stanach Zjednoczonych.

Antoni Popiel zmarł 7 lipca 1910 roku w Lubieniu koło Lwowa, dokąd udał się na kurację, nie doczekawszy jednej z najbardziej doniosłych chwil w dziejach polskiej sztuki za oceanem, jakim było uroczyste odsłonięcie jego dzieła (wspomnianego pomnika Kościuszki) w samym sercu Ameryki.

Nie wiemy, niestety, kto sprawił, że przy dekorowaniu jasielskiego kościoła zatrudniony został właśnie A. Popiel: czy była to inicjatywa franciszkanów (prowincjała, gwardiana), fundatora ołtarza głównego, architekta Michała Łużeckiego, rzeźbiarza Sokulskiego czy też kogoś z licznego grona dobrodziejów zakonu. Warto zaznaczyć, że M. Łużecki, projektant jasielskiej świątyni i wielu elementów jej wyposażenia, chętnie zajmował się aranżowaniem wnętrz sakralnych, projektując ołtarze, ławki, konfesjonały itp. elementy. Jego udokumentowana działalność $\mathrm{W}$ tym zakresie dotyczy nawet lat 30 . XX wieku ${ }^{34}$. Współpracował przy tym $\mathrm{z}$ różnymi twórcami.

Wiadomo, iż projektując jasielski kościół M. Łużecki przewidywał istotną rolę rzeźby w jego dekoracji. Przekonuje o tym odnaleziony w krakowskim archiwum franciszkanów projekt jasielskiego kościoła, który zakładał usytuowanie na jego wieży, nad głównym wejściem do świątyni, rzeźbionej figury (fot. 9). Jak się wydaje, na ówczesnym etapie architekt planował usytuowanie tu jednak figury patrona kościoła, bowiem naszkicowana na projekcie postać trzyma na lewej ręce

${ }^{33}$ Artyście temu poświęcona jest monografia: L. Lameński, Stach z Warty. Szukalski i Szczep Rogate Serce, Lublin 2007.

${ }^{34}$ Por.: Materiały do dziejów sztuki sakralnej na ziemiach wschodnich dawnej Rzeczypospolitej, red. Jan K. Ostrowski, cz. I: Kościoły i klasztory rzymskokatolickie dawnego województwa ruskiego (dalej: Materiaty, cz. I), t. 11, s. 113 i 115-117. 
Dzieciątko, co odpowiada ikonografii typowej dla św. Antoniego (fot. 10) ${ }^{35}$. Kto i kiedy wpłynął na zmianę tej roboczej koncepcji nie wiemy, być może była ona konsekwencją decyzji o umieszczeniu figury tego świętego w centrum głównego ołtarza. Nie można również wykluczyć, iż figura Matki Boskiej, i to w takim właśnie układzie, stanowi odbicie prac projektowych prowadzonych przez architekta w 1904 roku we Lwowie, celem wzięcia udziału w konkursie na projekt aranżacji studni, którą wieńczyć miała figura Matki Boskiej, wykonana w 1859 roku przez monachijskiego rzeźbiarza Jana Nepomucena Hauttmanna (fot. 11) ${ }^{36}$.

Przywołany projekt kościoła nie uwzględniał natomiast obecności na fasadzie franciszkańskiego godła, widać zatem, że propozycja przedstawiona przez architekta ewoluowała, nie tylko w odniesieniu do ostatecznego kształtu świątyni, ale i jej dekoracji. Architektura kościoła, niezwykle skromna i oszczędna w wyrazie, już z samego założenia nie dawała rzeźbiarzowi zbyt dużego pola do popisu. Niemniej jednak, zgodnie z tradycją architektury lwowskiej, w budynku zaprojektowanym przez reprezentanta tamtejszego środowiska, nie mogło zabraknąć akcentów rzeźbiarskich.

Ze źródeł archiwalnych wiemy, że godło zakonne nad wejściem do kościoła wykuwał na miejscu pomocnik A. Popiela, określony w źródłach jako Albrycht. Chodzi tu niewątpliwie o Andrzeja Albrychta (1878-1937) ${ }^{37}$. Rzeźbiarz ten działał we Lwowie, znane są też jego dzieła znajdujące się w Kałuszu, Kamionce Strumiłłowej i Samborze. Wiele lat swej działalności, przed i po I wojnie światowej, spędził w uznanym warsztacie rzeźbiarsko-kamieniarskim Henryka Karola Periera (1863-1928), wykonującym m.in. wiele nagrobków zamawianych na lwowski Cmentarz Łyczakowski. W ramach tego warsztatu A. Albrycht wykonywał odpowiedzialne prace, otrzymując najczęściej do opracowania partie figuralne nagrobków czy pomników. Jego specjalnością była rzeźba w kamieniu, z zakresu której prowadził nawet (w okresie międzywojennym) wykłady w lwowskiej szkole przemysłowej. Swoją działalność artystyczną prowadził także na Cmentarzu Orląt Lwowskich. Wiadomo również, że udanie skopiował krucyfiks Slackera autorstwa Wita Stwosza, a którą to kopię Maria Kulikowa podarowała w 1939 roku do kościoła Karmelitów na Persenkówce we Lwowie ${ }^{38}$. Odnaleziona wzmianka

${ }^{35}$ Teoretycznie mogła to być również figura św. Józefa, brak jednak przekonywującego uzasadnienia dla takiej hipotezy.

${ }^{36} \mathrm{O}$ konkursie tym pisze J. Lewicki, Między tradycja a nowoczesnościa. Architektura Lwowa lat 1893-1918, Warszawa 2005, s. 154-155, a o autorstwie figury Biriulow, Rzeźba lwowska, s. 62 i il. XXIII. Co ciekawe, konkurs ten - zakończony zresztą zwycięstwem Łużeckiego - był następstwem tego, że figurę postanowiono przenieść z pl. Mariackiego, gdyż na jej dotychczasowym miejscu stanąć miał wspomniany już pomnik Adama Mickiewicza autorstwa Antoniego Popiela.

${ }^{37}$ Zob.: Biriulow, Rzeźba lwowska, passim (zwłaszcza s. 178-179). Wcześniej w literaturze naukowej publikowana była tylko drobna wzmianka o jego późnej twórczości - por.: Albrecht Andrzej, w: SAP, t. I: A-C, Wrocław-Warszawa-Kraków-Gdańsk 1971, s. 17. Na temat odmiennego brzmienia nazwiska rzeźbiarza zob. przyp. 38 .

${ }^{38} \mathrm{O}$ dziele tym, Andrzeju Albrychcie i zjawisku kopiowania dzieł Stwosza w środowisku lwowskim zob.: Materiały, cz. I, t. 12, 2004, s. 288 i 291 oraz Materiaty, cz. I, t. 13, 2005, s. 117. W obu tych tomach nazwisko rzeźbiarza podane zostało w brzmieniu: „Albrecht”, jak się wydaje niewłaściwym, wobec brzmienia: „Albrycht” odnalezionego w materiałach źródłowych i stosowa- 
o współpracy A. Albrychta z A. Popielem przy godle franciszkańskim do kościoła w Jaśle rzuca nowe światło na wczesne lata działalności tego rzeźbiarza, wskazując na fakt, że swe pierwsze zawodowe kroki stawiał on właśnie w warsztacie tego uznanego twórcy, który nawet poza warsztatem nie wahał się powierzać mu wykonania odpowiedzialnych prac, do jakich niewątpliwie zaliczyć można wykuwane na miejscu godło do tympanonu w portalu jasielskiego kościoła.

Komentując te dwie realizacje warto jeszcze przypomnieć, że sytuowanie na elewacjach frontowych kościołów rzeźbionych grup lub pojedynczych figur, emblematów oraz inskrypcji związanych z ich wezwaniem czy specyficzną rolą lub funkcją, było w owym czasie, tj. na przełomie XIX i XX wieku, powszechną praktyką. Dekorowano w ten sposób liczne galicyjskie kościoły, by wymienić stosunkowo bliskie omawianemu terytorialnie: jasielski kościół wizytek (z płaskorzeźbą, względnie figurą, św. Michała Archanioła) czy kościoły parafialne w Ciężkowicach (figura Maryi), Korczynie (z figurami Chrystusa i Maryi) i Staromieściu (dzisiaj część Rzeszowa; z figurą patrona kościoła, św. Józefa) (fot. 12) ${ }^{39}$.

Kolejnym elementem łączącym postać M. Łużeckiego z jasielskimi pracami A. Popiela jest główny ołtarz franciszkańskiej świątyni. Został on zaprojektowany przez M. Łużeckiego, a wykonany w lwowskiej pracowni Tadeusza Sokulskiego. Ta do niedawna niemal zupełnie anonimowa postać została ostatnio wydobyta na światło dzienne dzięki badaniom Jurija Biriulowa ${ }^{40}$. Wynika z nich, że T. Sokulski urodził się około 1846 roku w Łańcucie, gdzie uczył się snycerstwa i stolarstwa artystycznego u swego ojca. W 1867 roku osiadł we Lwowie, pracując początkowo w pracowni stolarskiej Jana Smutnego, a od 1876 roku prowadząc i systematycznie rozwijając własną pracownię. W swej działalności ściśle współpracował z głównymi indywidualnościami lwowskiego świata artystycznego: architektem Julianem Zachariewiczem ${ }^{41}$ i wspomnianym już rzeźbiarzem L. Marconim, przyszłym teściem A. Popiela. Pierwszy z nich opracowywał szkice, a drugi przygotowywał modele, na podstawie których T. Sokulski wykonywał konkretne dzieła. Oprócz J. Zachariewicza wśród jego współpracowników spotykamy innych lwowskich architektów: Adolfa Kuhna i Jana Tomasza Kudelskiego. Chociaż zakład T. Sokulskiego zdobył uznanie dzięki licznym realizacjom

nego konsekwentnie w przywoływanej tu syntezie rzeźby lwowskiej XVIII-XX wieku autorstwa Jurija Biriulowa.

${ }^{39}$ W Galicji szczególnym propagatorem figuralnych dekoracji rzeźbiarskich na fasadach kościołów był związany z Krakowem i Lwowem Teodor Talowski. Więcej na ten temat zob.: W. Bałus, Grupa Ukrzyżowania na fasadzie kościoła Św. Elżbiety we Lwowie, „Przegląd Wschodni”, 6 (1999/2000) z. 2 (22), s. 311-324.

${ }^{40}$ Zob.: Biriulow, Rzeźba lwowska, w szczególności s. 138-140. Sokulski wielokrotnie wymieniany jest przy okazji różnych prac (wykonywania dzieł nowych lub renowacji starych) prowadzonych w obiektach sakralnych, zwłaszcza lwowskich, na łamach kolejnych tomów Materiałów, cz. I.

${ }^{41} \mathrm{Na}$ temat Zachariewicza zob.: B.S. Czerkies, I.O. Danczak, Architekt Julian Zahariewicz w ukraińskiej i polskiej kulturze, w: Ochrona wspólnego dziedzictwa kulturowego, red. J. Kowalczyk, Warszawa 1993, s. 72-85, a także: A. Laskowski, Międzynarodowa konferencja , Julian Zachariewicz i znaczenie jego działalności w XXI stuleciu”, „Biuletyn Historii Sztuki”, 61 (1999) nr 3-4, s. $510-512$. 
świeckim do prestiżowych gmachów we Lwowie (Politechnika Lwowska, Sejm Galicyjski, ratusz), to jednak główną jego specjalnością były realizacje kościelne, w szczególności ołtarze i prospekty organowe, ale także ambony, ławki kościelne, tabernakula, feretrony i inne sprzęty. W większości posiadały one pełnoplastyczne figury lub płaskorzeźby z motywami figuralnymi. Za swoją działalność zakład T. Sokulskiego był wielokrotnie nagradzany. Po 1910 roku jego aktywność uległa wyraźnemu zahamowaniu, sam T. Sokulski zmarł po 1916 roku.

Wśród kościelnych realizacji T. Sokulskiego odnajdujemy wiele prac godnych uwagi. Zaliczają się do nich trzy neośredniowieczne, dostosowane do stylu budowli, ołtarze główne wykonane w ostatniej dekadzie XIX stulecia, niektóre według projektu Kudelskiego: jeden do kościoła Sacré-Coeur we Lwowie ${ }^{42}$, drugi do kościoła parafialnego w Kochawinie k. Stryja, bardzo chwalony przez prasę ${ }^{43}$, trzeci do kościoła parafialnego $\mathrm{w}$ Skolem ${ }^{44}$. Pierwszy z nich (fot. 13), chociaż niewielkich rozmiarów, przypominał nieco swą budową ołtarz w Jaśle. Był wprawdzie pięcioosiowy i nad tabernakulum posiadał ażurowy baldachim (arkadę?), jednak - podobnie jak w Jaśle - główne jego osie wyznaczały ażurowe, lekkie, zwieńczone smukłymi pinaklami baldachimy, pod którymi umieszczone były pojedyncze figury. Dzięki takiemu zabiegowi całość drewnianej struktury ołtarzowej nabierała lekkości, penetrowana swobodnie przez światło padające z okien. Dość statyczne figury w tak lekkiej obudowie osiągnęły pożądany efekt, sytuując się w centrum uwagi widza, o co przecież chodziło zleceniodawcom, nadającym każdemu ołtarzowi konkretny program.

W kontekście ołtarza u jasielskich franciszkanów w działalności Tadeusza Sokulskiego warto jeszcze zwrócić uwage na dwa szczegóły. Otóż w latach 1895-1898 wykonał on trzy neogotyckie ołtarze (główny i dwa boczne), zaprojektowane przez J. Zachariewicza, do lwowskiego kościoła karmelitanek bosych. W ołtarzu głównym, poświęconym w połowie 1899 roku, znalazły się rzeźby autorstwa A. Popiela, wówczas jeszcze artysty na dorobku ${ }^{45}$. Jego struktura, naśladująca ołtarz szafiasty, nie wykazuje podobieństw do struktury ołtarza jasielskiego, odmienne w charakterze są również rzeźby, aczkolwiek łączy je niewątpliwie z jasielską rzeźbą św. Antoniego wyraźny realizm postaci. Z kolei w roku 1905, na zlecenie Rudolfa Haasego, T. Sokulski wykonał prospekt organowy w lwowskim kościele pw. św. Mikołaja, zaprojektowany przez M. Łużeckiego ${ }^{46}$. Takie następstwo faktów - jeśli zgodne jest z rzeczywistością - sugeruje, że jasielska współpraca M. Łużeckiego z T. Sokulskim mogła znaleźć na gruncie lwowskim szybką

${ }^{42}$ Por.: Biriulow, Rzeźba lwowska, s. 139, il. 91 oraz Materiaty, cz. I, t. 12, 2004, s. 32 i 39 oraz il. 15. Nadmienić można, iż kilka lat później, bez związku z pracami Sokulskiego, rzeźbę Najświętsze Serce Jezusa wyrzeźbił do tego kościoła Antoni Popiel (por.: Materiały, cz. I, t. 12, 2004, s. 34).

${ }^{43}$ Materiaty, cz. I, t. 9, 2001, s. 65, 70 i 76, il. 73.

${ }^{44}$ Tamże, s. 182 i 185 , il. 223 i 226.

${ }^{45}$ Materiaty, cz. I, t. 12, 2004, s. 136, 141 i 151 oraz il. 375, 376, 379, 391 i 392.

${ }^{46}$ Por. przyp. 30. W świetle informacji zawartych w: Materiaty, cz. I, t. 19, 2011, s. 327-328 „w r. 1899 Haase zbudował nowy instrument (na koszt gminy miasta Lwowa i parafii), którego drewniany prospekt wykonał rzeźbiarz Tadeusz Sokulski według projektu Michała Łużeckiego", co sugeruje, iż prospekt ten mógł powstać wcześniej, między 1899 a 1905 rokiem. 
kontynuację. Natomiast niezależnie od czasu wykonania przez T. Sokulskiego wspomnianego prospektu, zestawienie go z pracami do Jasła pozwala włączyć M. Łużeckiego w krąg architektów lwowskich współpracujących z Sokulskim. Widać przy tym pewną prawidłowość, a mianowicie nieprzypadkową ciągłość współpracy: wspólne działanie z A.Popielem jako spadkobiercą L. Marconiego (zmarłego wiosną 1899 roku) i z M. Łużeckim jako bardzo bliskim współpracownikiem J. Zachariewicza (zmarłego pod koniec 1898 roku).

Warto zwrócić uwagę, że opracowania naukowe z zakresu historii sztuki dotyczące A. Popiela - zarówno biogramy, jak i artykuły czy wzmianki na temat jego twórczości - ignorują zarówno jego realizacje jasielskie, jak i prace powstałe w okolicach Jasła. Warto więc przypomnieć, że twórca ten zaprojektował także (wykonaną przed rokiem 1908 w przemyskiej pracowni Majerskiego) kamienną figurę Ukrzyżowanego Chrystusa, umieszczoną we wnęce znajdującej się na zewnątrz prezbiterium kościoła parafialnego w pobliskich Kołaczycach, na jego osi głównej (fot. 14) ${ }^{47}$. Z kolei w kościele parafialnym w nieodległych Gorlicach, na jednym z filarów międzynawowych, umieszczone zostało wykonane przezeń $\mathrm{z}$ brązu popiersie Jadwigi z hr. Zborowskich Płockiej ${ }^{48}$. Na podstawie tych przykładów można mniemać, że dokładne prześledzenie różnorakich opracowań, zapisków i relacji z pewnością pozwoliłoby na znaczne rozszerzenie katalogu dzieł tego artysty w bliższej i dalszej okolicy.

Należy również przypomnieć, że A. Popiel był młodszym bratem Tadeusza (1863-1913), znanego i powszechnie szanowanego malarza historycznego, ucznia i protegowanego samego Jana Matejki ${ }^{49}$. Antoni, stawiając pierwsze kroki w świecie sztuki, podążał ścieżkami znanymi już swemu starszemu i utytułowanemu bratu (Kraków, Wiedeń), zgodnie zresztą z ówczesnymi realiami geopolitycznymi i geografią sztuki. Tadeusz, rozchwytywany w kraju i we Włoszech po wygraniu konkursu na dekoracje malarską kaplicy św. Stanisława w katedrze w Padwie (zrealizowaną w roku 1899), pracował m.in. dla krakowskich franciszkanów, zdobiąc freskami i witrażami nawę główną ich kościoła oraz wykonując na zewnątrz prezbiterium mozaikę. Pomimo wspólnych artystycznych zainteresowań bracia

${ }^{47}$ Sarna, Opis powiatu, s. 559. Nie można wykluczyć, iż efektowne (złote, mozaikowe) tło tej kompozycji powstało z inspiracji lub wręcz było dziełem brata Antoniego, malarza Tadeusza Popiela, który do kościoła w Kołaczycach zaprojektował witraże, a dla krakowskich franciszkanów wykonał znakomitą mozaikę Stygmatyzacja św. Franciszka. O rodzinie Majerskich i działalności ich warsztatu zob.: B. Podubny, Majerski Ferdynand Gerard, w: Przemyski stownik biograficzny (dalej: PrSB), red. L. Fac, T. Pudłocki, A. Siciak, t. 2, Przemyśl 2011, s. 66-74; B. Podubny, Majerski Stanisław Kostka, PrSB, t. 2, Przemyśl 2011, s. 74-82.

${ }^{48}$ Popiersie to odnotowano w artykule Materjały regjonalne Zagłębia jasielskiego, „Młody Geograf", 1 (1930) z. 3, s. 43, myląc imię artysty z imieniem brata (Tadeusz zamiast Antoni) i zwracając uwagę, iż nosi ono ślady kul i odłamków pocisków armatnich z czasów I wojny światowej.

${ }^{49}$ Zob.: Popiel Tadeusz, w: E. Swieykowski, Pamiętnik TPSP w Krakowie 1854-1904, Kraków 1905, s. 225-226; P. Błoński, Popiel (Sulima Popiel) Tadeusz (1863-1913), PSB, t. 27, Kraków 1983, s. 578-580; A. Wierzbicka, Popiel (Sulima Popiel) Tadeusz, SAP, t. 7: Pe-Po, Warszawa 2003, s. $398-404$. 
Popielowie dość rzadko działali razem, dekorując te same miejsca czy obiekty ${ }^{50}$. Wśród takich miejsc podać można: Teatr Miejski we Lwowie, kaplicę Matki Boskiej Pocieszenia w kościele pw. śś. Piotra i Pawła tamże oraz właśnie kościół franciszkanów w Jaśle. W tym ostatnim miejscu T. Popiel działał kilka lat później od brata, wykonując dla jasielskiej świątyni dwa obrazy (Niepokalana Dziewica Maria i Św. Franciszek) do ustawionych w kościele w 1909 roku dwóch ołtarzy bocznych ${ }^{51}$. Oba te dzieła nie zachowały się, zostały zniszczone wraz z kościołem w ostatnich miesiącach II wojny światowej. Nie są również znane żadne przekazy ikonograficzne, które dokumentowałyby ich wygląd.

W świetle najnowszych badań, miejscem, w którym już wcześniej zogniskowała się działalność wszystkich omówionych tutaj twórców był lwowski kościół bernardynek. Miało to miejsce w roku 1898, po tym, jak Rada Miejska Lwowa wykupiła skasowaną niegdyś świątynię z rąk państwa i rozpoczęła zakrojone na szeroką skalę prace, zmierzające do przywrócenia tego obiektu do kultu. Projekt niezbędnej przebudowy sporządzili wówczas J. Hochberger i M. Łużecki, polichromię wnętrza odnowił i uzupełnił T. Popiel, ambonę wyrzeźbił T. Sokulski, rzeźby do ołtarza głównego, przedstawiające św. Kazimierza i św. Kingę, wykonał A. Popiel, a prace kamieniarskie realizował H. K. Perier, w którego warsztacie - jak już wspomniano - zatrudniony został z czasem A. Albrycht, wówczas już dwudziestoletni mężczyzna ${ }^{52}$.

Szukając wzorców dla kompozycji ołtarza głównego u jasielskich franciszkanów, warto zwrócić uwagę na jej podobieństwa z ołtarzem głównym w kościele franciszkańskim w Krakowie (fot. 15) ${ }^{53}$. Struktura ta, licząca sobie w owym czasie już ponad 40 lat, musiała być jasielskim zakonnikom doskonale znana i być może to oni zasugerowali projektantowi odniesienie się w pracy dla Jasła, do form tegoż ołtarza. W efekcie obie realizacje łączy: strzelistość, fundamentalna rola elementów i detali architektonicznych, trójosiowość zaakcentowana baldachimami i pinaklami, zastosowanie dekoracji maswerkowej współgrającej z maswerkami okien w tle oraz wyeksponowanie centralnego pola kompozycji ołtarza, w którym umieszczony jest jego główny element dekoracyjny. Zastosowanie takie-

${ }^{50}$ Ciekawego przykładu wzajemnego portretu braci dostarcza Biriulow, Rzeźba lwowska, s. 121, wskazując na wykonane przez Antoniego w 1898 roku gipsowe popiersie Tadeusza. Działaniem w jednym obiekcie, ale w pewnym odstępie czasu i przy wykonaniu dzieł nie pozostających w bezpośrednim związku, był udział obu artystów w wykonywaniu elementów wyposażenia katedry łacińskiej we Lwowie (Materiały, cz. I, t. 21, s. 60-61, 83 i 95-96).

${ }^{51}$ Świstak, Franciszkanie, s. 20. Bardzo rozległa działalność Tadeusza Popiela wciąż czeka na rzetelne opracowanie. Nie brak jego dzieł w okolicach Jasła, a i w samym mieście był on jeszcze autorem zaginionego obrazu Nawiedzenie w ołtarzu głównym kościoła wizytek, zburzonego w czasie II wojny światowej jak kościół franciszkanów (zob.: Z. Świstak, Wizytki jasielskie, Jasło 1997, s. 30-31).

${ }^{52}$ Materiaty, cz. I, t. 19, s. 80-81 i 84-85. Wiadomo również, iż w 1899 roku tenże Perier wykonał zaprojektowaną przez Antoniego Popiela tablicę pamiątkową umieszczoną w katedrze łacińskiej we Lwowie w związku z setną rocznicą urodzin Klementyny z Tańskich Hoffmanowej (Materiały, cz. I, t. 21, s. 60-61 i 95-96).

${ }^{53}$ O ołtarzu tym zob.: E. Mikołajska, Neośredniowieczne oltarze w Krakowie, w: Sztuka sakralna Krakowa w wieku XIX, cz. 1, Kraków 2004, s. 143-148. 
go wzorca jest $\mathrm{z}$ jednej strony naturalne w świątyni franciszkańskiej, z drugiej jednak strony zaskakuje, gdyż stoi w opozycji do ogólnej tendencji tego czasu, polegającej na nawiązywaniu do struktur ołtarzy szafiastych ${ }^{54}$.

Jak się wydaje, potencjalnym źródłem inspiracji dla projektanta ołtarza niekoniecznie musiały być obiekty o tym samym przeznaczeniu czy o zbliżonej skali. Dla przykładu: bliski schematowi kompozycyjnemu ołtarza jasielskiego jest schemat neogotyckiej monstrancji z figurkami umieszczonymi pod baldachimami, znajdującej się w kościele parafialnym w Lipnikach, datowanej na przełom XIX i XX wieku ${ }^{55}$.

Nieco uwagi warto poświęcić programowi ikonograficznemu ołtarza. Był on stosunkowo skromny, ale być może dzięki temu większa była siła jego oddziaływania i wymowa. Oczywiście głównym elementem ołtarza była usytuowana na osi i najlepiej wyeksponowana figura św. Antoniego. Jej obecność w tym miejscu thumaczyć można wezwaniem nowej parafii i samego kościoła. Towarzyszące jej figury ukazują św. Alfonsa i św. Franciszka Salezego. Ich obecność wiąże się z postacią fundatora ołtarza, o. Alfonsa Franciszka Ptaszka, który zapragnął umieścić na ołtarzu figury swoich patronów ${ }^{56}$. Wydaje się możliwe, że umieszczenie tam wizerunku św. Franciszka Salezego mogło być zarazem gestem w stronę osiadłych w Jaśle w tym samym mniej więcej czasie sióstr wizytek ${ }^{57}$, których zgromadzenie zakonne założone zostało na początku XVII wieku, właśnie z inicjatywy św. Franciszka Salezego. Dobór świętych, których figury ustawiono na ołtarzu, nie wskazuje na jakąś wspólną, łączącą ich myśl, poza faktem, że wszyscy uznani zostali doktorami Kościoła i że każdy z nich związany był z określonym zgromadzeniem zakonnym: św. Antoni - z franciszkanami, św. Alfons - z redemptorystami, a św. Franciszek Salezy - z wizytkami.

Warto wreszcie przyglądnąc się bliżej zachowanej figurze św. Antoniego. Wizerunek ten, jakkolwiek w drobnych szczegółach zmodyfikowany nieco w wyniku uszkodzeń wojennych i późniejszych, kilkukrotnych zabiegów konserwatorskich, w swoim ogólnym schemacie kompozycyjnym i zestawie atrybutów towarzyszących ukazanym postaciom zbliżony jest do stanu pierwotnego. Pozwala to na podjecie analizy ikonograficznej i porównanie go z innymi, znanymi wizerunkami tego świętego, dodajmy: na przełomie XIX i XX wieku jednego z najchętniej przedstawianych świętych niepolskich, przynajmniej na terenie Galicji. Cenną pomoc w tej analizie stanowi bogato udokumentowana fotografiami seria wydawnicza poświęcona kościołom i klasztorom rzymskokatolickim dawnego województwa ruskiego ${ }^{58}$, w których znajdowały się lub nadal znajdują licz-

${ }^{54}$ Zgodnie z nią natomiast nie sięgnięto w Jaśle (jak to jest w Krakowie) po kamień, a wystawiono ołtarz drewniany. Odejście od stosowania kamienia do budowy ołtarzy było wynikiem krytyki, jakiej poddano tą praktykę, uznając ją za niezgodną z duchem gotyku, który starano się w owych realizacjach naśladować (Mikołajska, Neośredniowieczne ołtarze, s. 147).

${ }^{55}$ Materiaty, cz. I, t. 7, 1999, s. 128 i il. 176.

${ }^{56}$ Sarna, Opis powiatu, s. 262. Autor ten podaje (s. 261), iż fundator ołtarza był „kustoszem kustodyi przemyskiej".

${ }^{57}$ Laskowski, Przybycie i pierwsze lata pobytu, s. 113-127.

${ }^{58}$ Materiaty, cz. I, t. 1-21, Kraków 1993-2013. 
ne dzieła sztuki ukazujące św. Antoniego, pochodzące z interesującego nas okresu i w wielu przypadkach wykonane przez twórców związanych - jak autor figury jasielskiej - z lwowskim środowiskiem artystycznym.

W wizerunku autorstwa A. Popiela mamy do czynienia z ukazaniem dwóch głównych postaci (św. Antoniego i Dzieciątka Jezus), co bywało regułą ${ }^{59}$, podobnie jak i to, że Dzieciątko najczęściej ukazywano w pozycji siedzącej, przy lewym ramieniu świętego, nad jego biodrem, podtrzymywane od dołu przez świętego lewą dłonią.

Sw. Antoniego przedstawiano z reguly w habicie franciszkańskim (o odpowiednim kolorze, z bardzo szerokimi rękawami i ze zwisającym na plecach kapturem), przepasanym wysoko sznurem $\mathrm{z}$ węzłami, z sandałami na nagich stopach. Nierzadko elementem towarzyszącym bywał podpięty do sznura w pasie różaniec, na ogół nie wyróżniający się szczególnie na tle fałdów habitu. W tym względzie wizerunek jasielski zwraca uwagę mocno rzucającym się w oczy, dużym krzyżem różańca, umieszczonym przy habicie, tuż pod prawą, luźno zwieszoną stopą Dzieciątka ${ }^{60}$.

Prawa ręka świętego, wolna od ciężaru, najczęściej ukazywana była przez artystów z lilią w dłoni, symbolizującą męczeństwo świętego. W figurze jasielskiej jest ona silnie ugięta w łokciu, święty trzyma lilię delikatnie, ale wszystkimi palcami ${ }^{61}$.

Dość różnorodnie ukazywane bywa w tego typu przedstawieniach Dzieciątko: może być Ono nagie, półnagie lub - jak w Jaśle - ubrane. Antoni Popiel wyrzeźbił je siedzące na zamkniętej księdze o grubej oprawie. Wśród innych znanych przedstawień tego tematu Dzieciątko siedzi na księdze otwartej, czasami na niej (otwartej lub zamkniętej) stoi, względnie siedzi (lub wręcz leży) bezpośrednio na ręce (lub rękach) świętego. Cechą godną uwagi w jasielskiej rzeźbie jest fakt, że Dzieciątko siedzi w dynamicznej pozie, jakby się energicznie ruszało, o czym świadczą: uniesiona ku górze lewa stopa (wsparta na krawędzi oprawy księgi i łydce drugiej nóżki) oraz żywa gestykulacja rąk.

Dzieciątko swoją lewą dłonią trzyma od góry (za wieńczący je krzyżyk) złote, królewskie jabłko, umieszczone między nogami, na udach. Ale jabłko bywa też trzymane przez Dzieciątko przy ciele, w lewej ręce. Innym atrybutem w tym miejscu bywał chleb (bochenki chleba). Czasami atrybutu nie było wcale.

${ }^{59}$ Bardzo rzadko zdarzają się przedstawienia św. Antoniego z Dzieciątkiem i dodatkowymi osobami (osobą). Tak jest np. w przypadku rzeźby z kościoła parafialnego w Kosowie (obecnie w kaplicy cmentarnej tamże), gdzie u stóp świętego klęczy łysy, brodaty żebrak, zwracający się doń w proszalnym, modlitewnym geście. Por.: Materiały, cz. I, t. 14, s. 187 (figura gipsowa, z przełomu $\mathrm{XIX/XX} \mathrm{wieku)} \mathrm{i} \mathrm{il.} 231$.

${ }^{60}$ Krzyż różańca rzadko bywał tak wyraźnie eksponowany - ma to miejsce m.in. w generalnie odległej od jasielskiej rzeźbie z kościoła parafialnego w Otyni (obecnie w kościele parafialnym w Ligocie Książęcej). Por.: Materiaty, cz. I, t. 14, 2006, s. 265 (rzeźba drewniana, polichromowana, sprzed 1939 roku) i il. 382.

${ }^{61}$ Pewne podobieństwo do tego ujęcia widać w figurze w kościele jezuitów w Kołomyi, jednak gest dłoni jest tam subtelniejszy, kwiat (niezachowany) trzymany tam jest tylko 2-3 palcami. Por.: Materiały, cz. I, t. 14, s. 169 (figura z drewna polichromowanego, z przełomu XIX/XX wieku) i il. 200. 
Różny bywa gest prawej ręki Dzieciątka. Na ogół jest to gest błogosławieństwa, ale zdarzały się też inne, np. łapanie świętego za ubranie, tuż pod szyją (za dekolt $)^{62}$. Bardzo charakterystyczny w jasielskim przedstawieniu gest łapania przez Dzieciątko świętego za podbródek pojawia się stosunkowo rzadko. Można go zaobserwować w rzeźbie z kościoła parafialnego w Otyni (obecnie w kościele parafialnym w Ligocie Książęcej), gdzie nieco zbliżony do jasielskiego jest również gest prawej dłoni świętego trzymającej lilię (obecnie niezachowaną) oraz fakt siedzenia Dzieciątka na zamkniętej księdze ${ }^{63}$. Jeszcze bliższa jasielskiemu przedstawieniu jest, nieistniejąca już, rzeźba udokumentowana w 1996 roku w kościele parafialnym w Rudzie Brodzkiej. Jej ówczesny stan nie był już kompletny, niemniej jednak widać wyraźne podobieństwa między oboma dziełami, na tyle duże, że łatwiej wykazać różnice. Zaliczyć do nich można: generalnie mniejszą subtelność rzeźby rudzkiej i inny układ ciał postaci, brak krzyża przy różańcu oraz brak aureol i jabłka, co mogło jednak wynikać ze stanu zachowania rzeźby, która nie posiadała już wówczas ani prawej dłoni świętego, ani nóg i lewej ręki Dzieciątka $^{64}$. Gest łapania za podbródek występuje również w płaskorzeźbie zdobiącej jeden z ołtarzy w kościele parafialnym w Buczaczu, sama kompozycja tego dzieła jest jednak zupełnie inna niż w Jaśle ${ }^{65}$. Z kolei za policzek dotyka świętego Dzieciątko w rzeźbie z kościoła Franciszkanek Najświętszego Sakramentu we Lwowie (obecnie w klasztorze Klarysek od Wieczystej Adoracji w Kłodzku), co jednak nie przemawia za uznanie tego dzieła za odpowiedni materiał porównawczy, z racji jego mocno uproszczonej formy, bliskiej pracom twórców ludowych ${ }^{66}$.

Rozszerzenie analizy na dzieła starsze i wykonane w innych technikach, pozwala na stwierdzenie, że analizowany gest nie był niczym nowym, znany jest bowiem chociażby z XVII-wiecznego obrazu z klasztoru dominikanów w Źółkwi (obecnie w klasztorze dominikanów w Lublinie), który w inwentarzu z 1706 roku określony został jako łaskawy ${ }^{67}$. Mimo, że jego kompozycja i szczegóły są odmienne od tych w rzeźbie jasielskiej, to jednak ukazanie owego gestu dowodzi jego długiego zakorzenienia w ikonografii św. Antoniego. Ale jego źródeł należy, jak się wydaje, poszukiwać w ikonografii maryjnej. Trudno w tym kontekście nie przywołać ikony Matki Boskiej Włodzimierskiej68 jako bardzo odległego czasowo pierwowzoru dla tego typu ujęć, ukazujących Dzieciątko przytulane i przytulające się, które czułym i pełnym zaufania gestem łapie opiekującą się Nim osobę

${ }^{62}$ Por.: Materiały, cz. I, t. 15, 2007, s. 15 (rzeźba drewniana, polichromowana, z początku XX wieku) i il. 9, a także: Materiały, cz. I, t. 2, 1994, s. 101 (obraz wykonany przez K. Sagnowskiego w 1871 roku) i il. 284.

${ }^{63}$ Por.: Materiaty, cz. I, t. 14, 2006, s. 265 (rzeźba drewniana, polichromowana, przed 1939 roku) i il. 383.

${ }^{64}$ Por.: Materiaty, cz. I, t. 13, 2005, s. 234 (rzeźba z gipsu) i il. 455.

${ }^{65}$ Por.: Materiaty, cz. I, t. 1, 1993, s. 20 (drewno polichromowane i złocone, początek XX wieku) i il. 78.

${ }^{66}$ Materiaty, cz. I, t. 12, 2004, s. 94 (drewno, koniec XIX wieku) i il. 155.

${ }^{67}$ Materiaty, cz. I, t. 2, 1994, s. 109-110 (malowany na płótnie, XVII wiek) i il. 282.

${ }^{68} \mathrm{H}$. Nouwen, The Icon of the Virgin of Vladimir. Belonging to God, w: tegoż, Behold the Beauty of the Lord. Praying with Icons, Notre Dame, Indiana 2007, s. 45-63. 
za szyję. Wizerunek ten doczekał się mnóstwa kopii i naśladownictw; sam należy do popularnego typu ikonograficznego Eleusa (Umileniie) ${ }^{69}$.

Na marginesie tych rozważań warto może jeszcze zasygnalizować bliskość ikonografii św. Antoniego z ikonografią św. Józefa. Sprawia ona, że gdyby nie charakterystyczna fizjonomia „starego Józefa” i odmienne elementy jego (świeckiego przecież) ubioru, to można byłoby $\mathrm{w}$ atrybutach, układach postaci i ich gestach (w tym także w geście łapania za podbródek) upatrywać dokładnych powtórzeń wizerunków św. Antoniego Padewskiego ${ }^{70}$.

Powyższe rozważania prowadzą do wniosku, że jasielska rzeźba św. Antoniego autorstwa A. Popiela jest dziełem na wskroś oryginalnym. Jej twórca nie sięgnął wprost po żaden z powszechnie znanych wzorców przedstawień świętego, lecz starał się na ich bazie stworzyć nowe, autorskie dzieło, tworząc swoistą syntezę wizerunku Antoniego w oparciu o dotychczas stosowane rozwiązania. Sięgnął tym samym do popularnej w dobie historyzmu metody, jaką był eklektyzm, najlepiej rozpoznany i opisany w odniesieniu do architektury ${ }^{71}$. Stosowana we wczesnej, a następnie późnej fazie historyzmu metoda twórcza nie była zjawiskiem jednorodnym i niezmiennym. Eklektyzm późnego historyzmu odznaczał się w pełni świadomym łączeniem w ramach jednego dzieła różnorodnych form z przeszłości, doskonale rozpoznanych i opisanych w poprzedzającym późny historyzm okresie dojrzałego historyzmu. Był to zatem nie eklektyzm bazujący na intuicyjnym odbiorze przeszłości, lecz na rzetelnej wiedzy o minionych epokach i stylach. Celem takiego działania było stworzenie dzieła nowego, zdolnego wyrazić ducha epoki, w której powstało.

Mając na uwadze liczne rzeźbiarskie wizerunki św. Antoniego powstałe na przełomie XIX i XX wieku do kościołów rzymskokatolickich na Kresach, podkreślić warto ponadprzeciętną klasę dzieła A. Popiela. Spośród kilkudziesięciu rzeźbiarskich realizacji tego tematu reprodukowanych w Materiałach jedynie może rzeźby: $w$ kościele parafialnym w Hałuszczyńcach ${ }^{72}$, z kościoła parafialnego w Chorostkowie (obecnie w tamtejszej cerkwi) ${ }^{73}$ i z kaplicy Franciszkanek Rodziny Maryi we Lwowie (obecnie w Domu Generalnym w Warszawie) ${ }^{74}$ zbliżają się poziomem artystycznym i stopniem wysublimowania bądź ekspresją do rzeźby jasielskiej. Spośród nich, tylko o rzeźbie lwowskiej wiadomo, że była szczególnie wyeksponowana poprzez umieszczenie jej w głównym ołtarzu, po lewej stronie przedstawienia głównego (Św. Rodzina).

\footnotetext{
${ }^{69}$ W. Molé, Ikona ruska, Warszawa 1956, s. 20.

${ }^{70}$ Por. np. obraz z kaplicy publicznej w Czarnuszowicach, znajdujący się obecnie w tamtejszej cerkwi - Materiały, cz. I, t. 11, 2003, s. 83 (obraz olejny na płótnie, 2. połowa XIX wieku) i il. 133 - czy obraz z zespołu klasztornego SS. Franciszkanek Najświętszego Sakramentu we Lwowie, znajdujący się obecnie w klasztorze SS. Klarysek od Wieczystej Adoracji w Kłodzku - Materiały, cz. I, t. 12, 2004, s. 94 (obraz olejny na płótnie, koniec XIX wieku) i il. 139.

${ }^{71}$ P. Krakowski, Z zagadnień architektury XIX wieku. Historyzm i eklektyzm, w: Sztuka 2. połowy XIX wieku, Warszawa 1973, s. 23-36.

${ }^{72}$ Materiały, cz. I, t. 16, 2008, s. 101 (drewno polichromowane, początek XX wieku) i il. 166.

${ }^{73}$ Materiaty, cz. I, t. 17, 2009, s. 79 (gips polichromowany, początek XX w.) i il. 134.

${ }^{74}$ Materiaty, cz. I, t. 12, 2004, s. 129 (drewno polichromowane, w ołtarzu z 1897 roku) i il. 344.
} 
Z obserwacji tej wynika, że artysta podszedł do powierzonego mu przez franciszkanów zadania z pełnym zaangażowaniem, poświęcając rzeźbie przeznaczonej do centralnego miejsca w głównym ołtarzu jasielskiej świątyni wiele uwagi. Być może ta pieczołowitość miała pewien związek z faktem, że A. Popiel rzeźbił wizerunek swojego świętego patrona.

\section{Podsumowanie}

„Szkoda naszego kościoła w Jaśle. Tym żywiej odczuwamy jego stratę, że wznosił się, ozdabiał za naszej pamięci, więc widzi się ile to wysiłków, trosk, poszło w takim jednym budynku na marne!" - zapisano w 1945 roku w kronice krakowskiego klasztoru franciszkanów ${ }^{75}$. Żal jest tym większy, jeśli uświadomimy sobie rangę artystyczną dzieł, jakie zostały wraz z nim unicestwione u schyłku okupacji niemieckiej. Prace A. Popiela odgrywały w tej grupie istotną rolę, chociaż nie były jedynymi spektakularnymi pracami, jakie zamówili bądź sprowadzili na początku XX wieku do Jasła franciszkanie.

Warto zapytać, czego dowiadujemy się o Antonim Popielu z dzieł wykonanych dla jasielskich franciszkanów. Wydaje się, że przez ich pryzmat możemy go postrzegać jako bardzo wprawnego twórcę, działającego w różnych materiałach (kamieniu i drewnie), wykonującego dzieła o różnym przeznaczeniu (rzeźby i płaskorzeźby o charakterze architektonicznym, dopełniające architekturę oraz rzeźby pełnoplastyczne, współtworzące harmonijną całość z małą architekturą), trzymającego się kanonów ikonograficznych, a równocześnie starającego się nadać rzeźbionym przez siebie postaciom indywidualny, oryginalny wyraz, będący efektem eklektyzmu zaczerpniętych z różnych źródeł motywów. Widzimy go również jako sprawnego organizatora, kierownika warsztatu, osobę prowadzącą osobiście korespondencję ze zleceniodawcą, ale równocześnie otoczoną pomocnikami wykonującymi część prac za nią, na miejscu, na podstawie jej projektów bądź wskazówek. $Z$ całą pewnością nie był to artysta przeciętny, jakkolwiek nie należał do grupy twórców awangardowych, otwierających nowe horyzonty w sztuce rzeźbiarskiej. Tworzył starannie i sumiennie, rzeźbiąc sprawnie na miarę potrzeb i oczekiwań szerokiego grona odbiorców, wychowanego w duchu XIX-wiecznego historyzmu. To w zupełności wystarczało, aby odsunąć od siebie widmo głodu ciążące nad kolegami po fachu z poprzedniego pokolenia, ale nie okazało się wystarczające, aby zapisać się w dziejach sztuki polskiej w takim chociażby stopniu jak stało się to udziałem tworzących już w tym czasie rzeźbiarzy młodego pokolenia, takich jak Wacław Szymanowski, Konstanty Laszczka czy Xawery Dunikowski.

Jedyna zachowana, a przez to możliwa do bliższego przeanalizowania jasielska praca Antoniego Popiela to pełnopostaciowa rzeźba ukazująca patrona kościoła i parafii. Pozornie przeciętna w swej warstwie artystycznej i obiegowa w swym ikonograficznym ujęciu, wyłamuje się ze schematów, jakie rzeźbie sakralnej 2. połowy XIX wieku narzuciły wyroby seryjne, wytwarzane w dużej ilości egzemplarzy w wyspecjalizowanych warsztatach austriackich, francuskich czy

${ }^{75}$ APF, sygn. A-I-14: Kronika klasztoru krakowskiego [za lata 1892-1968], mps, s. 241. 
niemieckich, a w Galicji umieszczane przede wszystkim w kościołach klasztornych i świątyniach parafialnych na prowincji. Masowa skala ich produkcji wpływała na przystępność ich ceny, a ta z kolei zachęcała do ich nabywania, zwłaszcza w warunkach, gdy skala potrzeb w zakresie wyposażania i dekorowania nowo wybudowanej świątyni była znacznie większa niż skala możliwości finansowych danej parafii, na ogół długo obciążonej zobowiązaniami z tytułu samej budowy kościoła. Na tle tego typu wyrobów masowych jasielska figura św. Antoniego zwraca uwagę indywidualnym podejściem do tematu, przy równoczesnym zastosowaniu eklektycznej postawy twórczej, charakterystycznej dla późnego historyzmu, polegającej na twórczym kompilowaniu elementów znanych z dzieł istniejących, celem stworzenia dzieła oryginalnego, niepowtarzalnego.

\section{ANEKS}

15 stycznia 1906 r. - List Antoniego Popiela do prowincjała franciszkanów [o. Peregryn Haczela]

Żródto: APF, sygn. D-II-44, teczka D-II JASŁO-3

Przewielebny Księże Prowincyale Dobrodzieju!

Jak wiadomo Przewiel. Księdzu Prowincyałowi że figury do Jasła odstawiłem jeszcze przed świętami i na tej podstawie udaję się z uniżoną prośbą o łaskawe udzielenie mi resztującej kwoty za wykonanie tychże. -

W tym celu śmiem przedstawić rachunek jak następuje:

W myśl umowy naszej za wykonanie i opakowanie dwóch figur Św. Alfonsa i Św. Salezego po 300 kor. razem

600 kor.

A conto pobrałem

300 kor.

Przy poprzednich robotach pozostało na rzecz tych figur

40 kor.

340 kor.

Pozostaje zatem do wypłacenia

260 koron

Jeżeli to Przewielebnemu Księdzu Prowincyałowi różnicy nie robi to prosiłbym o łaskawe przesłanie tej kwoty pocztą, gdyż w obecnym czasie jestem bardzo zajęty, jeżeli zaś nie to proszę łaskawie powiadomić mnię kartą kiedy mam przybyć. -

Łącząc wyrazy najwyższego szacunku i poważania pozostaję uniżonym sługą

15/1. 1906 r.

Antoni Popiel 


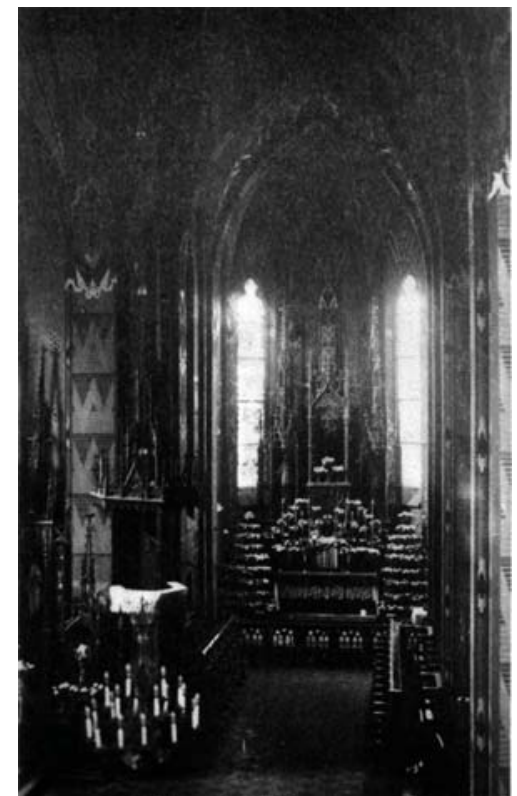

Fot. 1. Fragment wnętrza dawnego kościoła franciszkanów w Jaśle z widokiem na ołtarz główny. Reprodukcja wg: Świstak, Franciszkanie w Jaśle, s. 186/ Fragment of the interior of the former Franciscan church in Jasło facing the main altar. The reproduction based on: Świstak, The Franciscans in Jasło, p. 186.

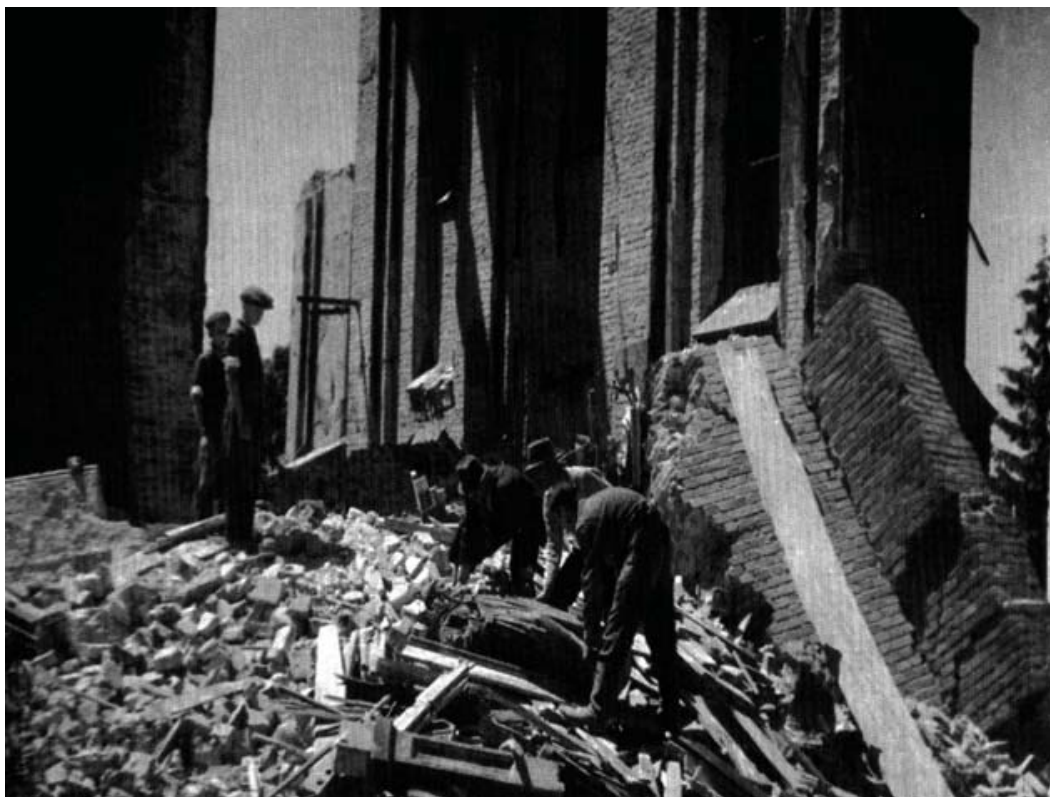

Fot. 2. Wydobycie figury św. Antoniego z ruin zburzonego przez Niemców kościoła franciszkanów w Jaśle. Fot. Stanisław Witowski-Iskrzyniak. Reprodukcja wg: Święty Antoni Padewski. Patron Jasła, oprac. Z. Świstak, Jasło 1996, bns/ Extracting the figure of St. Anthony from the ruins of the Franciscan church destroyed by the Nazis in Jasło. Photograph: Stanislaw Witowski-Iskrzyniak. The reproduction based on: St. Anthony of Padua. The patron saint of Jasło, ed. Z. Świstak, Jasło 1996. 


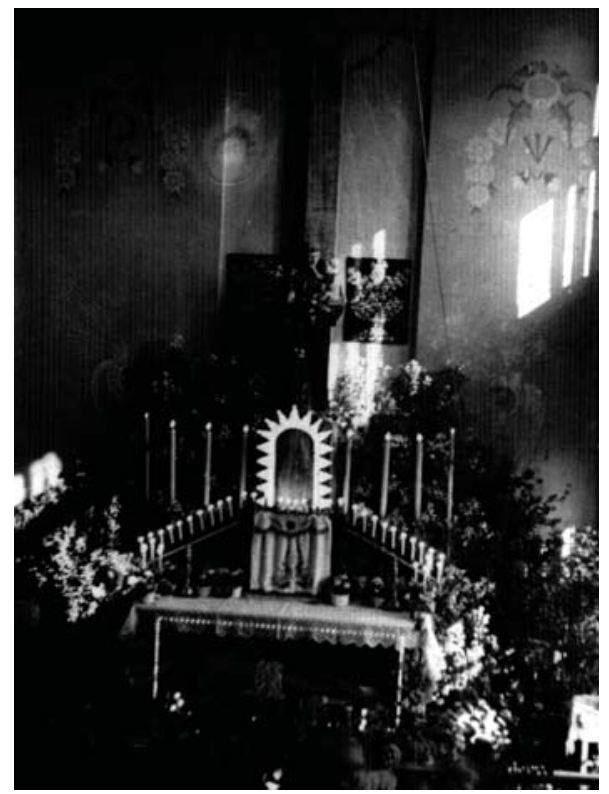

Fot. 3. Figura św. Antoniego ustawiona w ołtarzu głównym powojennej, tymczasowej kaplicy franciszkanów w Jaśle. Fot. Zdzisław Świstak. Reprodukcja wg: Święty Antoni Padewski, bns/ The figure of St. Anthony placed in the main altar of the post-war temporary Franciscan chapel in Jasło. Photograph: Zdzislaw Świstak. The reproduction based on: St. Anthony of Padua. The patron saint of Jasto

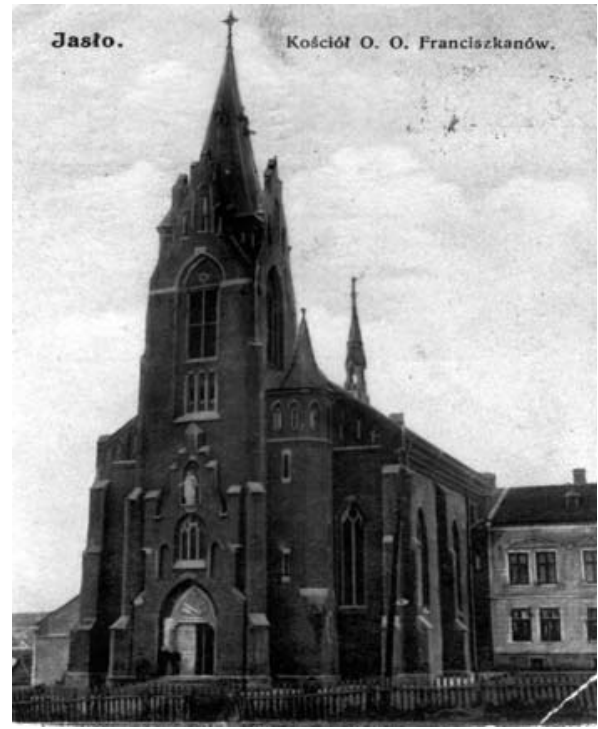

Fot. 4. Widok dawnego kościoła franciszkanów w Jaśle na pocztówce z 1915 roku. Zb. Jerzego Rucińskiego/ A general view of the old Franciscan church in Jasło on a postcard of 1915. The postcard from Jerzy Ruciński’s collection. 


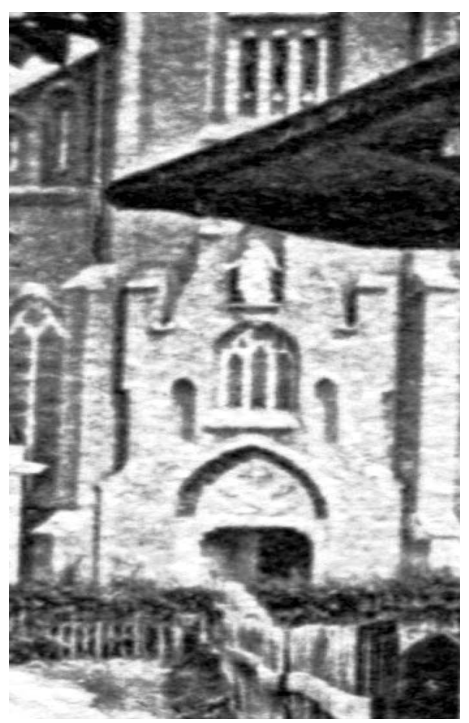

Fot. 5. Fragment pocztówki z 1914 r. z widokiem dawnego kościoła franciszkanów w Jaśle. Nad wejściem głównym godło zakonne oraz figura Matki Boskiej Niepokalanie Poczętej. Zb. Jerzego Rucińskiego/ Fragment of the postcard embossed in 1914 with a view of the old Franciscan church in Jasło. Above the main entrance there is a visible monastic emblem and the statue of Our Lady of the Immaculate Conception. The postcard from Jerzy Ruciński's collection.

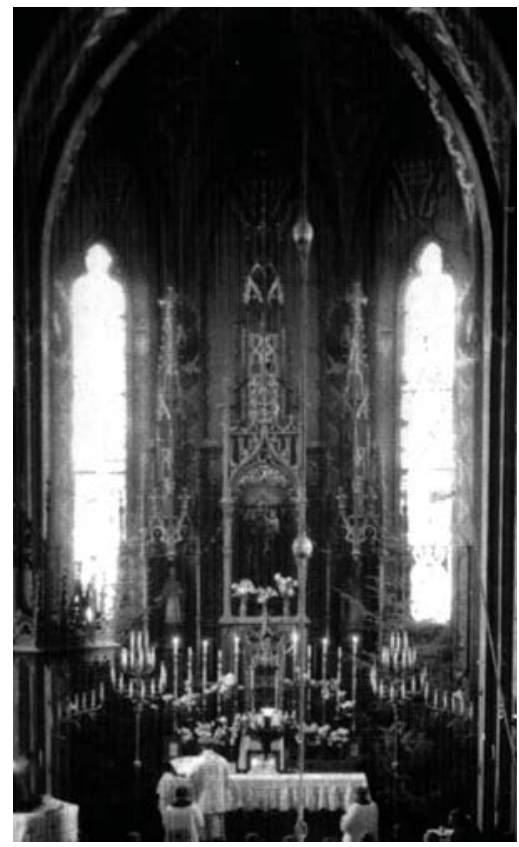

Fot. 6. Ołtarz główny we wnętrzu dawnego kościoła franciszkanów w Jaśle. Reprodukcja wg: Święty Antoni Padewski, bns./ The main altar inside the former Franciscan church in Jasło. The reproduction based on: St. Anthony of Padua. The patron saint of Jasto. 


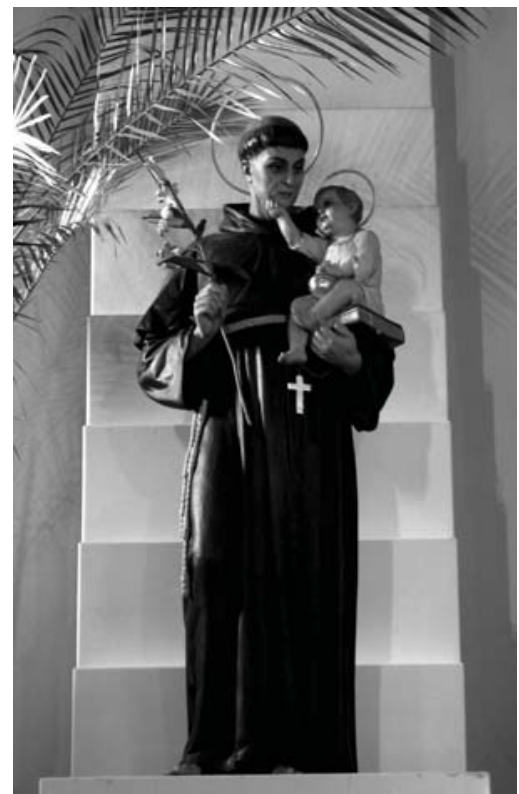

Fot. 7. Figura św. Antoniego w dzisiejszym kościele franciszkanów w Jaśle. Fot. Andrzej Laskowski, 2009/ The figure of St. Anthony in today's Franciscan Church in Jasło. Photograph: Andrzej Laskowski, 2009.

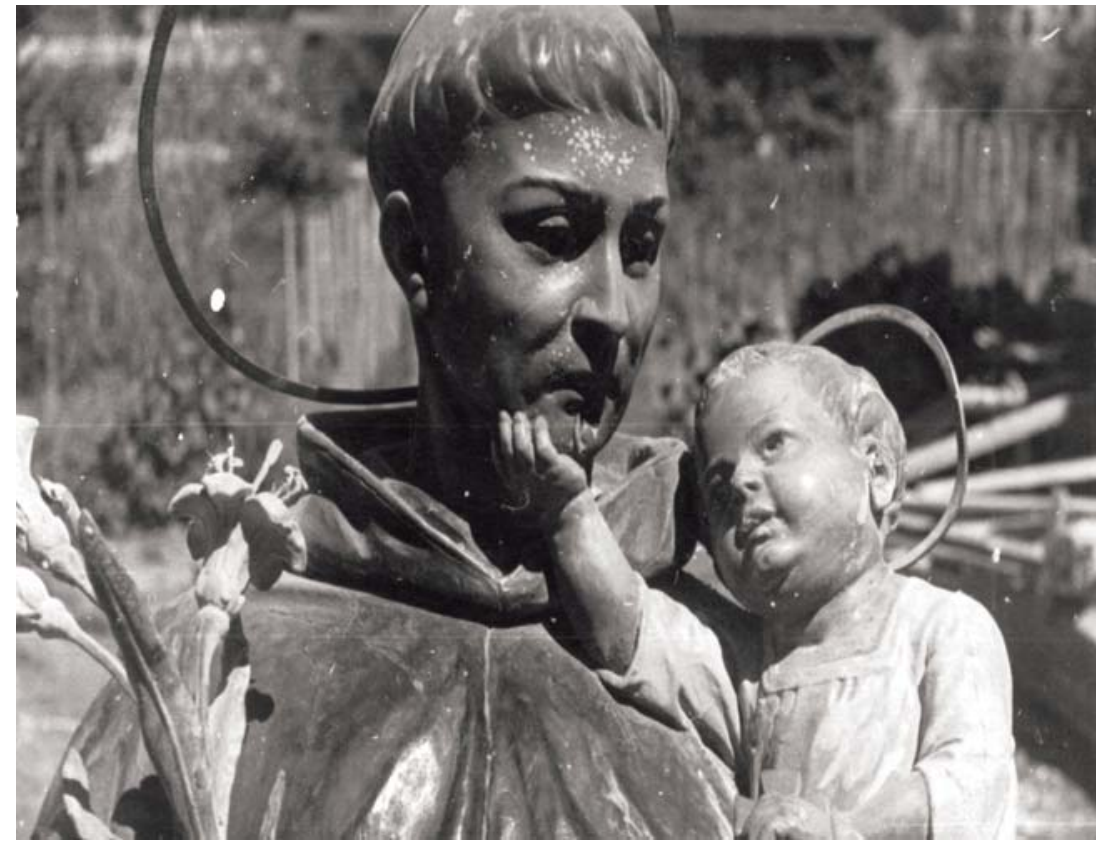

Fot. 8. Fragment figury św. Antoniego z dawnego kościoła franciszkanów w Jaśle, tuż po wydobyciu z ruin. Fot. Stanisław Witowski-Iskrzyniak. Zb. Jerzego Rucińskiego/ Fragment of St. Anthony figure from the main altar of the old Franciscan church in Jasło after extracting it from the ruins of the church. Photograph: probably Stanisław Witowski-Iskrzyniak. The reproduction from Jerzy Ruciński’s collection. 


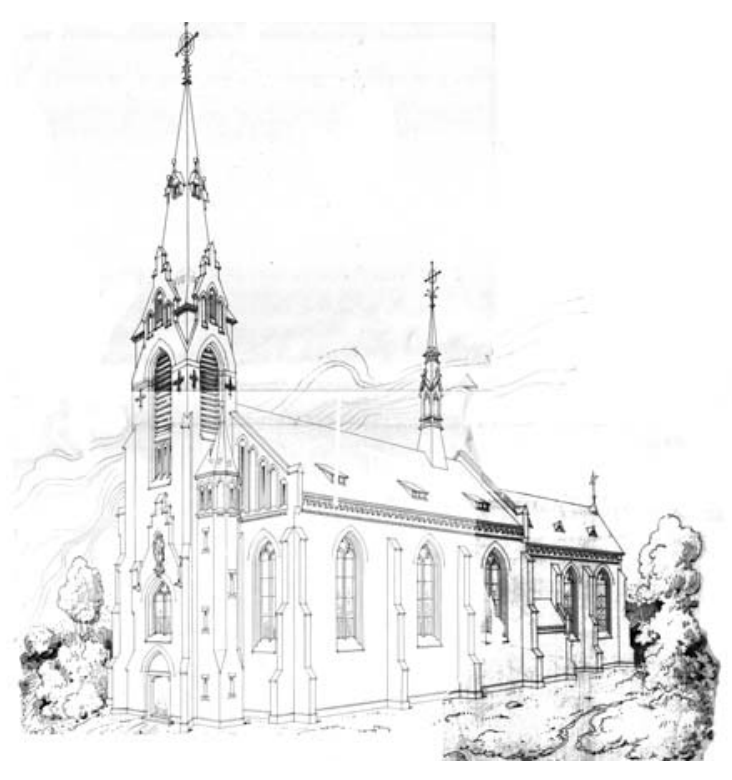

Fot. 9. Projekt dawnego kościoła franciszkanów w Jaśle - widok ogólny od południowego wschodu. Nie datowany, nie sygnowany. Oryginał w APF/ The project of the former Franciscan church in Jasło - a general view from the south-east. Undated, unsigned. Original in: the Archive of the Province of the Franciscans in Cracow

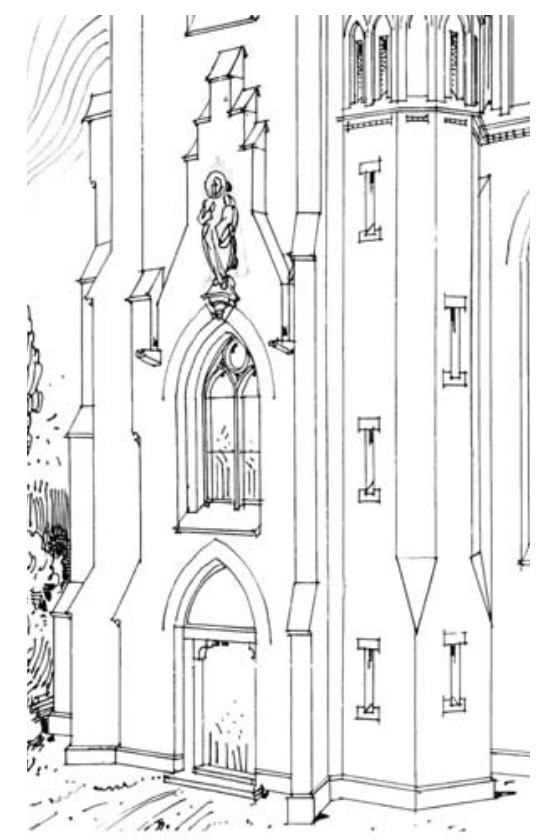

Fot. 10. Fragment il. 6 przedstawiający projekt partii wejściowej do kościoła franciszkanów w Jaśle. Oryginał w: APF/ Fragment of fig. 6 showing a project of an entrance to the Franciscan church in Jasło. Original in: APF 


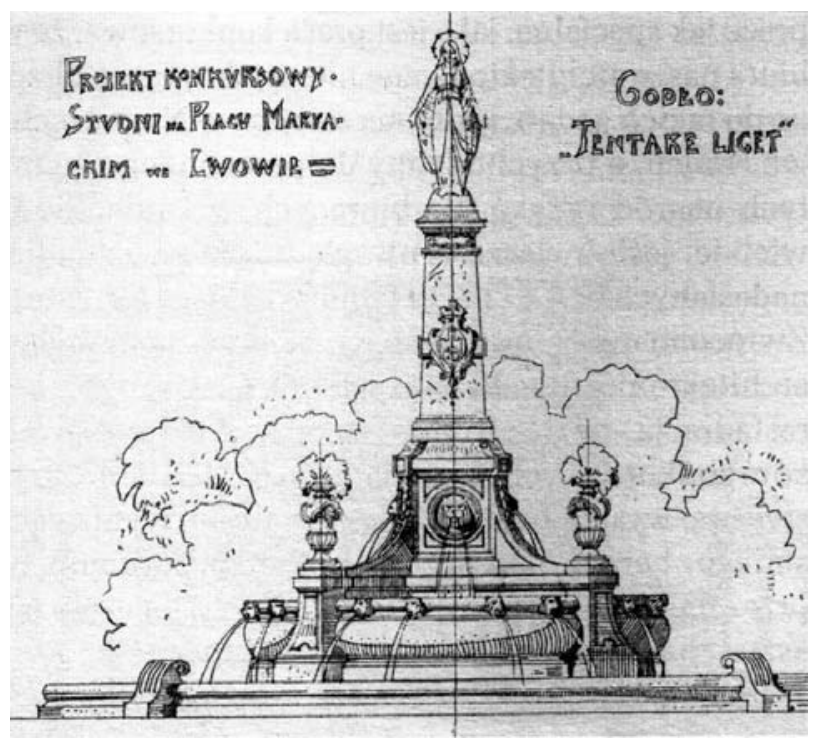

Fot. 11. Zwycięski projekt studni z figurą Matki Boskiej we Lwowie wykonany na konkurs przez Michała Łużeckiego. Wg: Lewicki, Między tradycją a nowoczesnością, s. 154, il. 54A/ The winning design of the well with the figure of the Virgin Mary in Lviv made for the contest by Michał Łużecki. Based on: J. Lewicki, Between tradition and modernity. Architecture of Lviv in the years 1893-1918, Warsaw 2005, p. 154, fig. $54 \mathrm{~A}$.

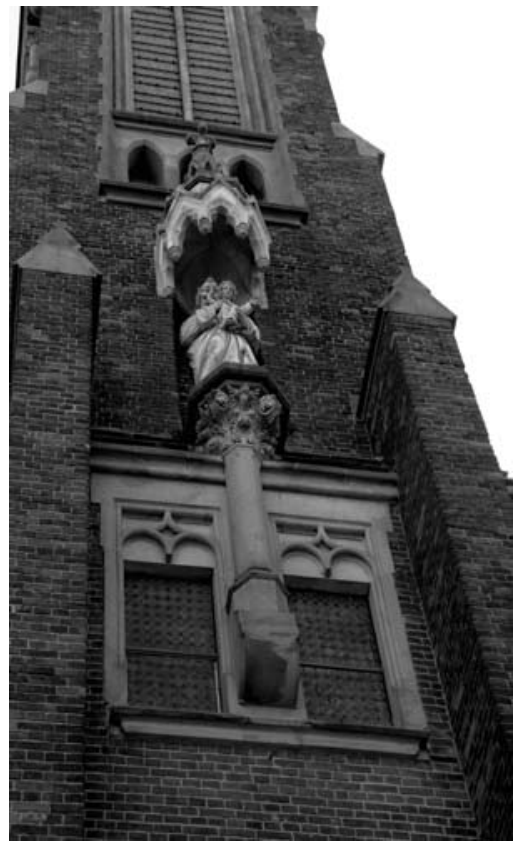

Fot. 12. Figura św. Józefa w elewacji frontowej kościoła parafialnego p.w. św. Józefa w Staromieściu (obecnie w granicach Rzeszowa) z początku XX w. Fot. Andrzej Laskowski, 2011/ The figure of St. Joseph in the front elevation of the parish church of St. Joseph in Staromieście (currently in Rzeszów) from the beginning of the twentieth century. Fig. Andrzej Laskowski, 2011. 


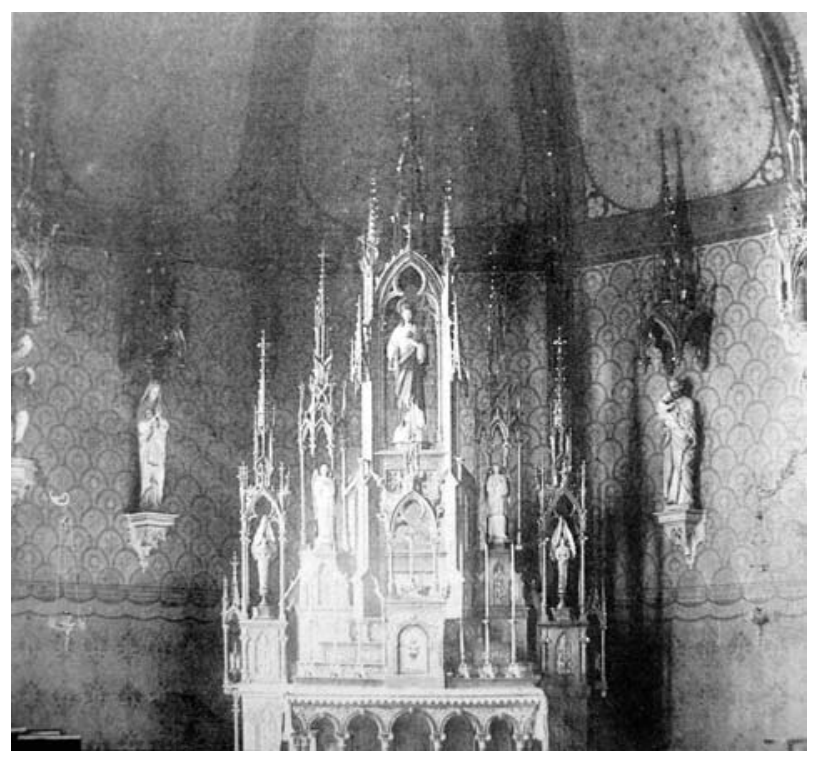

Fot. 13. Ołtarz główny w kościele Sacré-Coeur we Lwowie wykonany przez T. Sokulskiego. Reprodukcja wg: Biriulow, Rzeźba lwowska od połowy XVIII wieku do 1939 roku, s. 139, il. 91/ The main altar in SacreCoeur Church in Lviv made by T. Sokulski. The reproduction based on: J. Biriulow, The Lviv sculpture from the mid-eighteenth century until 1939. p. 139, fig. 91.

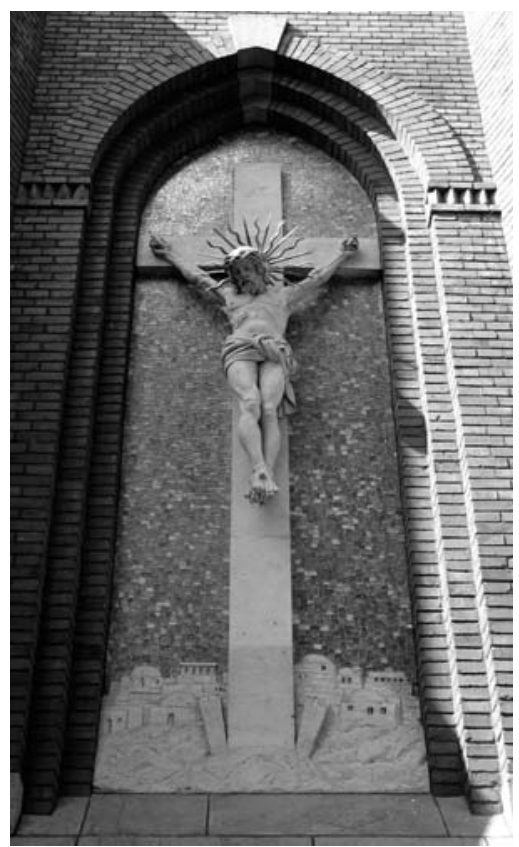

Fot. 14. Rzeźba Ukrzyżowanie autorstwa A. Popiela na ścianie zewnętrznej prezbiterium kościoła p.w. św. Anny w Kołaczycach. Fot. Andrzej Laskowski, 2009/ Crucifixion-sculpture by Antoni Popiel on the external wall of the chancel of the parish church dedicated to St. Anna in Kołaczyce. Photograph: Andrzej Laskowski, 2009. 


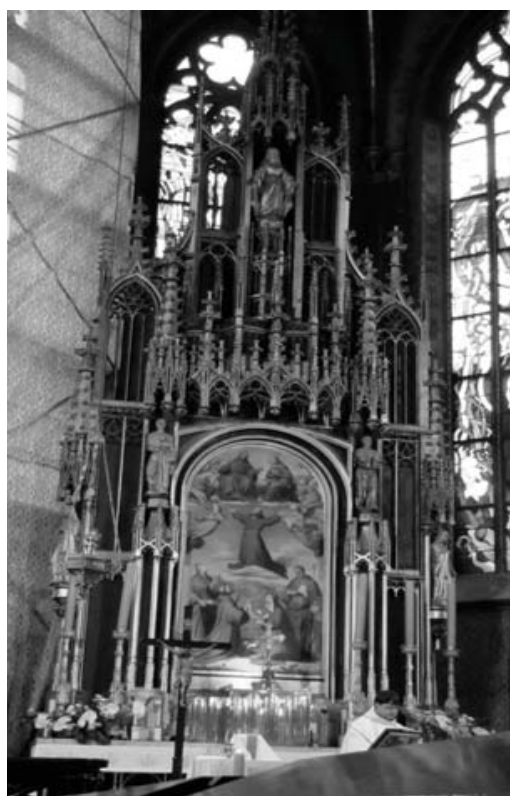

Fot. 15. Ołtarz główny w kościele Franciszkanów w Krakowie - stan obecny. Fot. Andrzej Laskowski, 2013 /The main altar in the Franciscan church in Cracow - present day. Photograph: Andrzej Laskowski, 2013.

Słowa kluczowe: Franciszkanie, św. Antoni Padewski, Jasło, Lwów, rzeźba, sztuka sakralna, Antoni Popiel, Michał Łużecki 


\title{
ANTONI POPIEL'S SCULPTURES FOR THE FRANCISCANS FROM JASLO
}

\begin{abstract}
Summary
The article discusses several elements of decoration and equipment of the Franciscan church in Jasło, destroyed during the Second World War, which was designed by Michał Łużecki, an architect from Lviv. These elements were created by a known Lviv sculptor Antoni Popiel. They are stone elements of church facade decoration (the statue of Our Lady of the Immaculate Conception and the bas-relief emblem of the Franciscan order) and wooden sculptures adorning the altar of the church, depicting such saints as: St. Anthony of Padua, Alphonsus and St. Francis de Sales. All were created in 1904-1905. These decorations evoke the names of the above mentioned sculptor's collaborators from Lviv: Albrycht, a stonemason (the emblem creator); Michał Łużecki, an architect (the designer of the altar) and Tadeusz Sokulski, a woodcarver (the altar creator).

Only one of Anthony Popiel's works made for the Franciscans in Jasło survived to the present day- the statue of St. Anthony. It was originally placed in the central place in the structure of the main altar of the destroyed church. Today it is in the side chapel of the new Franciscan church, built after the war at a new site. This figure, miraculously saved from destruction, has long been worshiped in Jasło, which in 1996 led to the recognition of St. Anthony of Padua as the patron saint of the town by the Town Council in Jasło. December 27, 2014 marks exactly a century since bringing the figure to Jasło.

The article draws attention to the artistic values of the preserved sculpture, comparing it with other representations of this saint of that time created in the area of influence of the artistic community of Lviv. It can be concluded that the sculpture from Jasło is the work of an artistic value, the work which is an individual interpretation of the theme proposed by the sculptor. It can also be noted that Anthony Popiel's works from Jasło, hitherto unknown to historians of art, are an interesting complement to his artistic achievements and significant contribution to the relationships between the sculptor and other artists associated with Lviv. The article is supplemented with the copy of Anthony Popiel's letter of January 15, 1906 to the Franciscan Provincial, Father Peregrine Haczela, containing the estimate of three figures for the main altar of the former Franciscan church in Jasło. The letter is stored in the Franciscan archive in Cracow.
\end{abstract}

Keywords: the Franciscans, St. Anthony of Padua, Jasło, Lviv, sculpture, religious art, Antoni Popiel, Michał Łużecki 